\title{
Scour development and large-diameter monopiles in cohesive soils: evidence from the field
}

\author{
John Harris ${ }^{1}$ and Richard Whitehouse ${ }^{1}$ \\ ${ }^{1}$ HR Wallingford, Howbery Park, Wallingford, Oxfordshire OX10 8BA, UK \\ Corresponding authors: John Harris, j.harris@hrwallingford.com; Richard Whitehouse, r.whitehouse@hrwallingford.com
}

Published in J. Waterway, Port, Coastal, Ocean, Eng., 143(5), ASCE. (2017)

\section{Abstract}

Despite the progress in scour research over the last three decades, seabed scour development in cohesive and non-uniform soils is still an area of great uncertainty and remains a challenge for designing structurally efficient and effective foundations in the offshore marine environment. The uncertainty is made greater by the time-scale required for scouring, effects such as sediment abrasion, pile installation impacts and operationally and environmentally induced dynamic motions. The rapid growth in offshore wind, particularly in European waters, has led to a requirement for estimates for scour development in such soils. This becomes very pertinent for large volume serial installation of foundations such as those required for offshore wind farm developments, given that there is a limit to the amount of detailed geotechnical information that can be collected as part of a project, and soil erosion testing is not standard. There is a reliance in geotechnical data such as undrained shear strength, derived from Cone Penetration Tests, supplemented with borehole data collected at a limited number of locations across the wind farm site combined with laboratory analysis of soil samples. This paper reviews the present evidence from both field and laboratory measurements of scour potential and looks at possible approaches to determine scour magnitude in cohesive soils including hydraulic and mechanical effects.

\section{Introduction}

Scour is both a hydrodynamic and a geotechnical process resulting from fluid-structure-soil interaction. It is a hydrodynamic process as it relates to the movement of the seabed sediment as a result of the flow of water past and away from the structure; whilst the soil conditions are described by geotechnical parameters, and scour is related to the reduction in ground level around a structure. Marine soils are typically variable in their makeup, consisting of a range of sediments, including sands, gravels, silts and clays. Van Ledden et al. (2004) defined six types of sediment bed based on sediment particle size distribution and the remoulded shear strength as a measure of cohesion.

It is common in the sediment transport literature for the terms clay and mud to be used interchangeably, although this is incorrect. Mud is typically defined as a mixture of water, clay, silt and fine sand, and also includes organic material and sometimes gas (e.g. hydrogen sulphide resulting from organic decomposition). In the UK mud is generally classified as having particle sizes of less than $63 \mu \mathrm{m}$, including silt, whilst clays have a plate-like structure, and generally have a diameter less than $2 \mu \mathrm{m}$. However, this classification is not 
universal, and other countries have their own particle size classifications, for example the United States Department of Agriculture classifies silt as less than $50 \mu \mathrm{m}$.

The use of a granular classification allows the nature of soil behaviour to be defined simply, i.e. cohesive, granular or mixed, and this has important implications for the mechanical and erosion properties of a sediment (Whitehouse et al., 2000; Winterwerp and van Kesteren, 2004). The degree of cohesion increases with the fraction of clay minerals within the sediment, and starts to become significant when the sediment contains more than 5-10 \% of clay by weight. The most important types of clay minerals are kaolinite, chlorite, montmorillonite, and illite. Depending on the geological inheritance and how they combine with the other materials depends on the formation history (environment) and the degree of compaction experienced. In offshore geotechnics, soils influenced by clay minerals are often referred to as clays.

For the purpose of this paper non-uniform soils/sediments are defined as those soils that consist of varying percentages of sands, gravels, silts and clays. Marine soils/sediments may consist of non-uniform and uniform sediment layers. However, for the purpose of this study the soils assessed are defined as behaving in a cohesive manner.

The paper covers a review of erodibility of soils, scour in cohesive soils and clays, erosion testing, abrasion, cyclic loading, evidence from field data on scour depth and time evolution. The paper covers the challenge of dealing with the combined fluid, structural and geotechnical problem before giving a practical application prior to drawing conclusions.

\section{Erodibility}

Workable definitions of the complete spectrum of soil types from pure cohesionless (granular) sands to clays can be obtained from soil mechanics testing. A range of soil parameter definitions have been prescribed and test procedures defined to help assess the performance of foundations (e.g. Terzaghi et al., 1996; Randolph and Gouvernec, 2011). These measures of soil properties have also been applied to try and obtain correlations between the hydraulic behaviour of the soil (i.e. threshold for erosion and erosion rate) and the properties of the seabed such as bulk or dry density and shear strength. This is an important parameter in the assessment of scour hazard.

Mirtskhulava (1966) noted from observations taken using a high speed camera (3,000 frames per second) the dependency of the erosion of cohesive soils on their composition, structural uniqueness, moisture content and degree of cohesion. Mirtskhulava also remarked on the force effects of the "pulsating bed flow" and how the coherence between the particles of the soil get "fatigued" such that erosion occurs when the resultant of the "active forces" exceeds the "passive ones". Mirtskhoulava (1991) states that the physical, chemical and mechanical properties of cohesive soils are the basic factors determining the soil's resistance to erosion. Further, Mirtskhoulava states that the cohesion at saturation water content and the size of the particle diameter appear to be the most significant of these properties, although the inhomogeneity of the soil also needs to be considered.

A range of data has also been presented from laboratory tests on under-consolidated cohesive sediments by Whitehouse et al. (2000). These provide a correlation between the bulk density of the sediment bed and the erosion shear stress, $\tau_{e}$. The equation covers a wider range of cohesive bed types: mixed beds, consolidated 
beds and blended high density beds up to bulk densities of $1800 \mathrm{~kg} / \mathrm{m}^{3}$. The relationship giving the erosion shear stress in newtons per square meter is of the form:

$\tau_{e}=E 3\left(\rho_{B}-1000\right)^{E 4}$

where $\rho_{\mathrm{B}}$ is the bulk density of the bed in kilograms per cubic meter, and E3 and E4 are dimensional coefficients (S.I. units) fitted to the data with $E 3=0.015$ and $E 4=0.73$. At $1800 \mathrm{~kg} / \mathrm{m}^{3}$ the erosion shear stress value is about $2 \mathrm{~N} / \mathrm{m}^{2}$.

The erodibility of clay soils has also been assessed in terms of direct geotechnical measures of bed strength. However, the analogy between the force required to strip the surface layers of a soil through the action of flowing water and the force required to shear the bed using a shear vane (which measures the torque force required to rotate a vane of a given shape and size) is not that clear. Individual studies have demonstrated that a reasonable correlation exists between the two measures (e.g. Kamphuis and Hall, 1983). Kamphuis and Hall found that the value of shear stress required for erosion increased with unconfined compressive strength, vane shear strength, Plasticity Index, and clay content of the soil, and with increasing preconsolidation pressure. The results of tests on a consolidated cohesive sediment (clay) showed the variation of threshold shear stress for erosion with the first two parameters was linear.

The data of Kamphuis and Hall showed the critical shear stress for erosion $\tau_{o c}$ in $\mathrm{Pa}$ or $\mathrm{N} / \mathrm{m}^{2}$ was linearly correlated with data for unconfined compressive strength $C_{u}$ in the range $20 \mathrm{kPa}$ to $80 \mathrm{kPa}$ as follows:

$\tau_{o c}=7.1+0.145\left(\frac{C_{u}}{10^{3}}\right)$

and with vane shear strength, $S_{v}$, in the range 5 to $25 \mathrm{kPa}$ as follows:

$\tau_{o c}=3.8+0.55\left(\frac{S_{v}}{10^{3}}\right)$

The values of $C_{u}$ and $S_{v}$ are input in pascals in Equations (2) and (3). However, a universal relation of the types presented by Kamphuis and Hall for both under-consolidated and consolidated sediments has not been achieved. One reason for this is that tests are carried out with different types of equipment, e.g. the shear vane integrates over a vertical element of the soil (> several $\mathrm{mm}$ and usually at a depth of several $\mathrm{cm}$ in the bed) and the reading is related to the macroscopic properties of the soil; also different shear vanes will have different dimensions and operating procedures. Another reason is the variation in the methods used to prepare the test soils.

Kamphuis and Hall found the resistance of a cohesive soil to erosion increased with clay content and Plasticity Index. As will be discussed later in the paper this increase is consistent with the observed reduction in scour with increasing clay content (Debnath and Chaudhuri, 2010; Dey et al., 2011; Schindler et al., 2016). One notable conclusion was, for the clay tested in their study, if the pre-consolidation pressure was greater than approximately $200 \mathrm{kPa}$ then the soil was considered safe from erosion under "normally expected, naturally occurring flow conditions". Chapuis (1986) noted that the consolidation methodology used by Kamphuis and Hall was not consistent with a standard oedometer test and, therefore, it is probable that the samples were only partially consolidated for the pressure applied. Whitehouse (2006) suggested firm clay with undrained shear strength of $100 \mathrm{kPa}$ is probably able to resist erosion in the open sea marine environment although it can be eroded in tidal rivers. Jiang et al. (2004) observed a scour depth of $5 \mathrm{~m}$ adjacent to an oil-unloading terminal in firm clay. So it is clear that in some environments it is necessary to treat stiff clay as a scour hazard. 
Winterwerp and Van Kesteren (2004, p.376) present formulae including undrained shear strength $S_{u}$ for mass erosion by "flow-induced pressures" under current action and waves. They present a figure showing data with values of $S_{u}$ up to about $0.16 \mathrm{kPa}$ (Figure 9.11, p.361). However, the values of the undrained shear strength are at least one order of magnitude smaller than typical values found in offshore soils so this method is not considered further.

Smerdon and Beasley (1959), investigated the critical tractive force for the general movement of soil placed loosely in a laboratory flume. The authors derived a correlation between the Plasticity Index (PI) for the soil and the critical tractive force. The original units for the critical tractive force were given in $\mathrm{lbs} / \mathrm{ft}^{2}$, however, converting into $\mathrm{N} / \mathrm{m}^{2}$ using the multiplication factor 47.88 (i.e. $1 \mathrm{lbs} / \mathrm{ft}^{2}=47.88 \mathrm{~N} / \mathrm{m}^{2}$ ) their equation becomes:

$\tau_{c r}=0.163(P I)^{0.84}$

with $\tau_{c r}$ now in newtons per square meter.

The data covers values of PI from about 7 through to 50 and critical threshold values up to about $4.8 \mathrm{~N} / \mathrm{m}^{2}$.

\section{Scour in cohesive soils and clays}

The principal body of work to date on scour in cohesive soils and clays is related to scouring around bridge piers. The prediction of scour in cohesive or multi-modal soils is more complex than in sands and gravels. Typically the scour process is much slower; as a result the effect of scour is very much dependent on the period of time that the structure will remain in place and the time history of the erosive forces. A conceptual model for relative scour depth was presented by Whitehouse (2006). At that time the evidence from offshore oil and gas and nascent offshore wind installations showed scour development in stiff clay was not generally considered to be an issue; broadly in line with conclusions on erosion from Kamphuis and Hall (1983).

Annandale (1995) proposed an approach to estimating the erosion potential of complex soils through the use of the stream power parameter, $P$, and its relationship to the ability of the soil to resist scour, defined through an Erodibility Index, $K$. The Erodibility Index provides a measure of the in-situ strength of the material, whilst the stream power provides a measure of the rate of energy dissipation in the near-bed region due to hydrodynamic forces. When $P$ exceeds the erosion threshold then scouring will occur.

Flume experiments by Hosny (1995) used fixed cylindrical piles, ranging in diameter from $0.1-0.15 \mathrm{~m}$ placed in different soil conditions varying from sediment mixtures (cohesive and non-cohesive sediments) to unsaturated and saturated cohesive soils. Hosny found that the local pier scour depth was affected by the clay content, soil compaction and initial water content. In addition, the cohesive content of the soil could reduce the final scour depth and the time-scale required to achieve maximum scour depth was greater in saturated cohesive soils than in sediment mixtures.

Hosny (1995) proposed a series of relationships between scour depth, pile diameter, clay content, soil compaction, initial water content and the strength of the flow characterised by the Froude Number. For sand - clay mixtures the maximum scour depth increases with increasing pile diameter and Froude Number and decreases as compaction increases:

$S_{\max }=18.9 D\left(\frac{F_{r}}{1+C}\right)^{2}$ 
For unsaturated and saturated cohesive soil the maximum scour depth increases with pile diameter and Froude Number and decreases as the product of initial water content and compaction increase:

$S_{\text {max }}=0.9 D(I W C)^{-2 / 3}\left(F_{r}\right)^{3 / 2} \operatorname{Comp}^{-2}$

Maximum scour depth, $S_{\max }$, as a function of volume of the scour hole $V_{s}$ was given as:

$S_{\max }=k D\left(\frac{V_{s}}{D^{3}}\right)^{k^{\prime}}$

In the above equations $D$ is the pile diameter, $C$ is the clay content, $F_{r}$ is the Froude Number, $F_{r}=U_{c} /(g h)^{0.5}$ and $U_{c}$ is the approach current speed, $g$ is the gravitational constant and $h$ is the water depth. IWC is the initial water content where $0.15<$ IWC $<0.5$, Comp is the degree of compaction where $0.58<$ Comp $<1, k$ is a constant and $k^{\prime}$ is a constant $\left(0.4<k^{\prime}<0.7\right)$.

Ivarson (1999) modified the HEC-18 (Richardson and Davis, 1995) $K_{4}$ factor for bed armouring in granular soils to account for the scour resistance for clay soils. The changes were based on studies carried out by Ettema (1980), Chee (1982) and Chiew (1984) for circular piles for both clear water and live bed conditions. The resulting equation is dimensionally inconsistent (as noted by Ivarson) and in this regard it is unsatisfactory. However, the equation has the right sort of behaviour with regards the effect of pier size and clay strength.

$K_{4}=0.677 \log \left(500 \frac{D}{C_{u}}\right)$

Where $D$ is the pile (pier) diameter in inches, and $C_{u}$ is the unconfined compressive strength of clay $\left(\mathrm{lbs} / \mathrm{ft}^{2}\right)$. This correction factor can be applied in the HEC-18 pier scour formula when $C_{u}$ is 17 times greater than the pier width in inches.

Equation (8) could be made dimensionally consistent by multiplying the pier diameter, $D$ by the unit weight of the soil, $\gamma$. This would require re-analysis against suitable experimental and field data.

Molinas et al. (1999) studied montmorillonitic cohesive soils and noted a distinction between pier scour occurring in unsaturated compacted soils compared with that occurring in saturated soils. In general they found that the local scour depth decreased as the initial water content decreases and increased as the Froude number $\left(F_{r}\right)$ increases (Figure 1). This was also observed in the data of Link et al. (2013) within the same initial water content range. They also state that the side slopes of the local scour holes formed in the tests were much steeper than those encountered in non-cohesive soils, although this may be a short-lived effect under the continuing action of flowing water and the influence of the turbulent wake behind the pile. Reflecting on the interpretation of this sort of data for the offshore marine environment, the water content shown in Figure 1 is comparable with some marine soils. Therefore the implication for offshore soils is for negligible scour. 


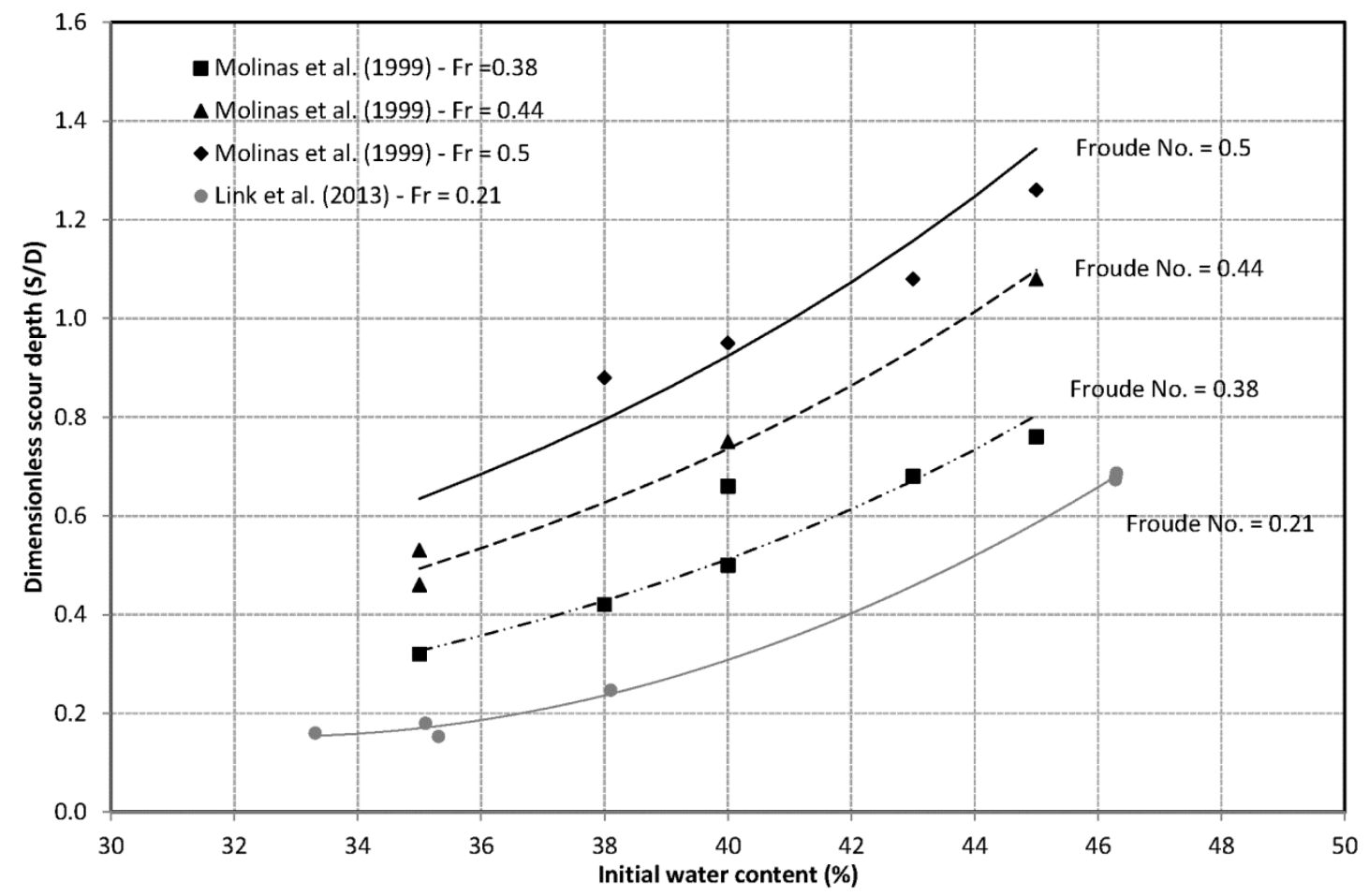

Figure 1. Effect of initial water content on local pier scour for a saturated cohesive soil under different approach flow conditions (after Molinas et al., 1999)

With regard to the use of the Froude number in scour prediction, this parameter is not physically representative of the scour mechanism in deeper water depths as it describes the ratio of the inertial to gravitational forces on the fluid, whilst the scour process is related to the interaction of water and sediment at the seabed.

Briaud et al. (1999) proposed an approach to predicting the scour depth and rate of scour in cohesive soils around a cylindrical bridge pier. The SRICOS method (Scour Rate In COhesive Soils) involved taking site specific samples and testing them in a laboratory Erosion Function Apparatus to obtain the rate of scour against the applied hydraulic shear stress, and combining this information with the maximum shear stress prior to scour developing. Having undertaken these steps the maximum scour depth for the given pier structure could be determined and then a hyperbolic function developed to describe the scour depth with time curve. The predictions obtained using this method were compared against measurements from 42 flume experiments.

Briaud et al. proposed a simple relationship for the maximum scour depth, $S_{\max }$, in metres based on the pier Reynolds number $R_{D}$ :

$S_{\text {max }}=0.00018 R_{D}^{0.635}$

where,

$R_{D}=\frac{U D}{v}$

and $U$ is the mean flow velocity, $D$ is the pier diameter and $v$ is the kinematic viscosity of the water. The formula is similar to that proposed by Shen et al. (1969) for scour in non-cohesive soils. 
$S_{e}=0.000223 R_{D}^{0.619}$

where $S_{e}$ is the equilibrium scour depth in metres. Comparing Equations (9) and (11) suggests the equilibrium scour in cohesive soils and non-cohesive soils is similar, in those cases where the cohesive soil is scourable.

Equation (9) is dimensionally inconsistent and ignores any effect of the soil. The tests upon which it was derived were limited to three clay types and this may also be a limitation in its application. The range of pile Reynolds number for the offshore field cases are likely to be several orders of magnitude greater than those for which the equation was developed. It should also be noted that Equation (9) disagrees with, for example, the Richardson and Davis (1995) HEC 18 method where the pile Reynolds number is not considered important for local scour in sands and gravels at large Reynolds numbers.

Ting et al. (2001) reported on experiments in the laboratory to study local scour at cylindrical piers in clay. They compared their results with experimental data for local scour in sand and investigated the effects of Reynolds number (Figure 2), Froude number and approach flow depth on the local scour depth. They compared their results with predictions obtained using the approach outlined in Richardson and Davis (1995). The results indicated that although the rates of scour in clay were much slower than in sand, the equilibrium scour depth was similar to that obtained in sand (confirming the conclusion regarding Equations (9) and (11) above). Ting et al. also noted that the shape of the scour hole correlated with the pier Reynolds number, with the scour developing relatively uniformly around the pier at low pier Reynolds numbers. At higher pier Reynolds numbers, the scour holes developed mainly behind the piers with much less scour forming in front of the piers. In a reversing tidal flow the scour would extend away from the pile to form a more symmetrical scour hole.

For the test conditions run, Ting et al. did not find any noticeable effect of Froude number and approach flow depth on scour depth. The experiments were carried out using five different sediment types, three clays (porcelain, armstone and bentonite) and two sands (fine, $d_{50}=0.14 \mathrm{~mm}$; and medium, $d_{50}=0.60 \mathrm{~mm}$ ). To put the data in context of Figure 1, the water content was in the range 28.5 to $39.3 \%$ and Froude numbers were in the range 0.1 to 0.42 ; the ratio of the approach flow depth to the pier diameter varied between 1.43 and 16. Seven scour tests were carried out using the two sands for comparison purposes.

The equilibrium scour depths given in Ting et al. (2001) were derived from fitting a hyperbola to the measured scour depth versus time curves. This was required due to the slow rates of scour in the clays used and the necessity to stop the tests before equilibrium conditions were achieved. This is a key issue in conducting scour experiments in cohesive soils and causes uncertainty in the reported experimental values.

The results and trend line of Briaud et al. presented in Figure 2 show reasonable agreement with the results of Shen et al. (1969) (compared with Equation (9) - the leading coefficient in Ting et al. relates to scour depth in $\mathrm{mm}$ ). The results of Shen et al. were valid for clearwater scour conditions only, as they found that, in the non-cohesive soils that they used, under live-bed conditions the sediment transport into the scour hole resulted in a decrease in scour depth. In cohesive soils, where the eroded particles remain in suspension, the scouring process essentially remains within the clearwater regime and the equilibrium scour depth increases with pier Reynolds number. Whether this approach is valid for cohesive marine soils is more difficult to determine as stiff glacial tills once eroded may release both granular sediment, silts and clays and some bedload transport may occur. Further, based on studies by Kamphuis (1983; 1990), for example, release of the non-cohesive granular material may impact on the erosion of the cohesive soil itself, either through protecting the bed locally or abrading parts of the seabed. 


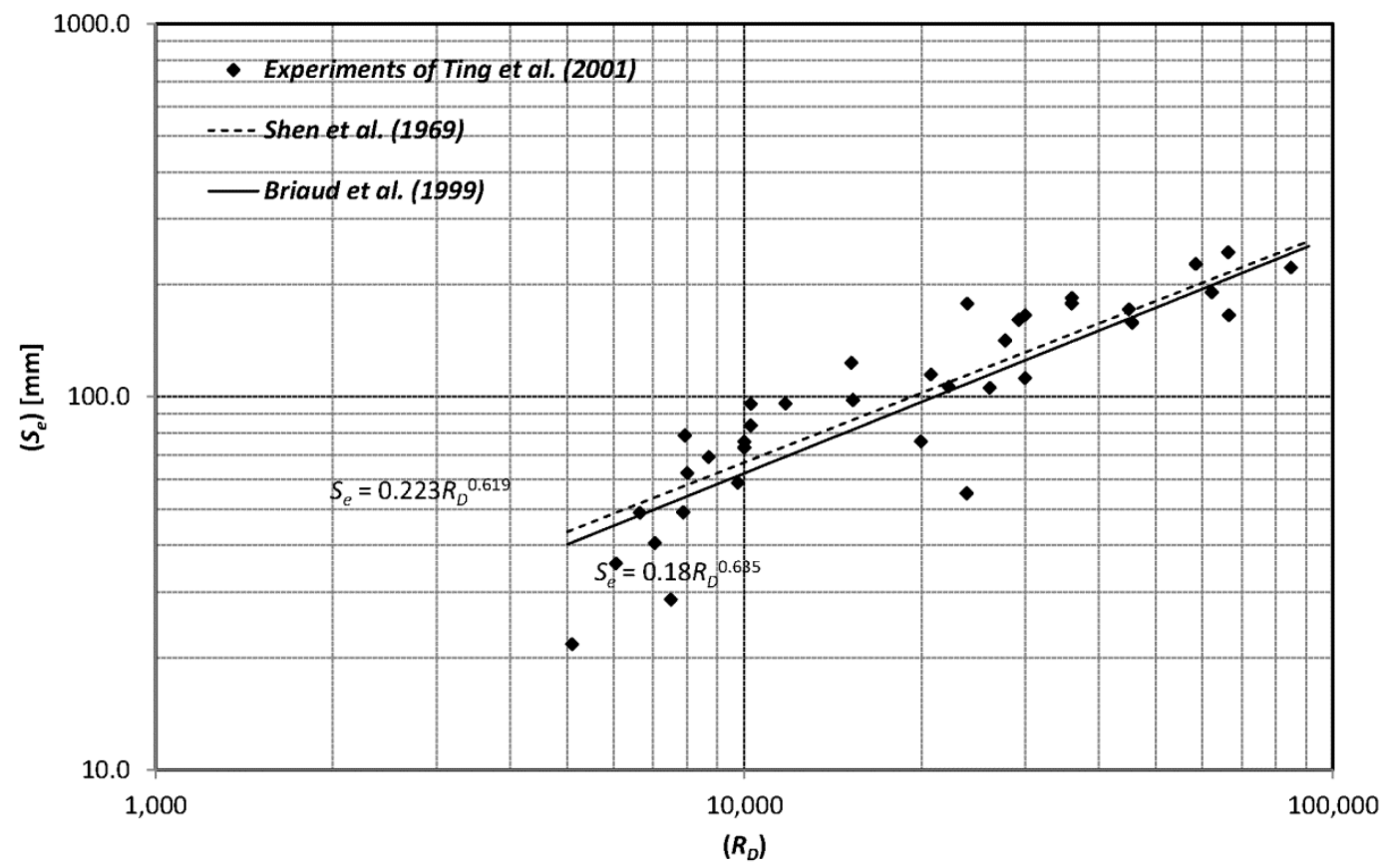

Figure 2. Variation of equilibrium scour depth with pier Reynolds number for clay and sand (after Ting et al., 2001)

The Reynolds number is important with respect to the scour process as it controls the separation point of the flow along the side of the cylinder (Achenbach, 1968). It also controls the shedding frequency of the lee wake vortices. Ettema et al. (2006) demonstrated that smaller cylinders produce more vorticity compared to larger cylinders (in their test case twice as much vorticity). Figure 3 shows a comparison of Reynolds number versus equilibrium scour depth for a range of laboratory experiments together with the maximum scour depth derived from Briaud et al. (1999). There is significant scatter in the data and this remains even allowing for the variation in clay content (analysis not shown). However, the scatter may also be a function of parameters such as soil plasticity (e.g. Smerdon and Beasley, 1959; Kamphuis and Hall, 1983) and moisture content (e.g. Molinas et al., 1999) and this has not been investigated further here. More interestingly is that the SRICOS approach and in particular the maximum scour depth predictor encompasses the majority of the other data sets. Therefore, this implies that Equation (9) should, in general, provide a conservative estimate of the maximum scour depth for cohesive soils.

Ansari et al. (2002) investigated the influence of cohesive sediments on scour around bridge piers under steady flows. They proposed a numerical model to calculate the temporal variation of scour depth in cohesive sediments based on the characteristics of the horseshoe vortex. The shear stress under the horseshoe vortex was determined through consideration of the initial magnitude of the principal vortex tube, which Ansari et al. proposed at the sides of the pier was 0.316 times that formed at the nose. Their model was compared against laboratory data. It is interesting to note that the results of the comparison are variable, with some test results comparing very favourably with the model, whilst in other tests the model fails to predict the initial onset of scouring well, but gives a reasonable fit towards the peak values. The authors attribute the model's poor fit at the start of the tests to dominance of scouring at the sides of the pier initially, whilst later in the tests scour development at the nose of the pier is dominant. Therefore, the model would appear to be better able to predict the maximum scour depth than the earlier stages of scour development. 


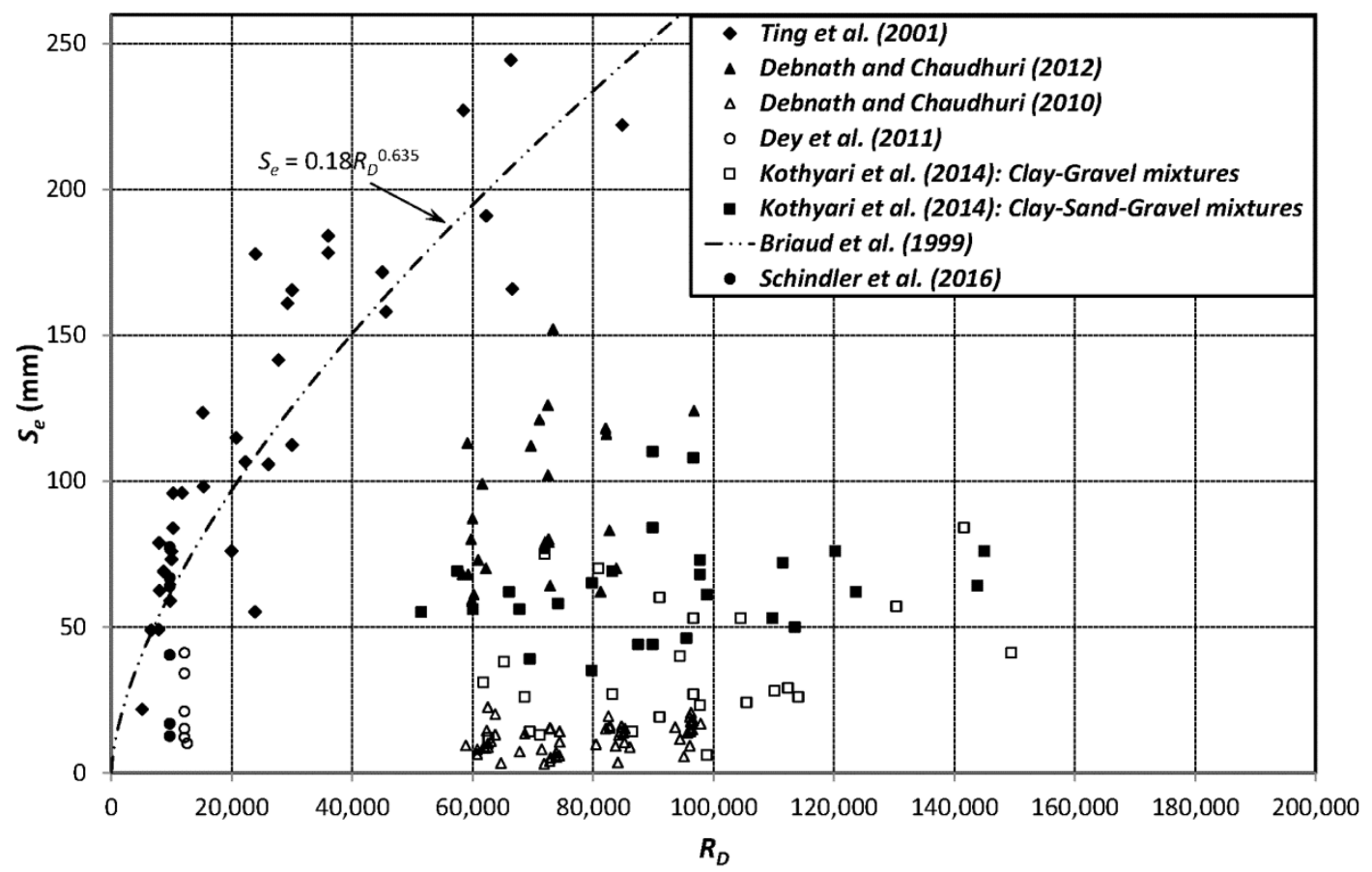

Figure 3. Variation of equilibrium scour depth with pier Reynolds number for clay

Rambabu et al. (2003) presented results from tests using three different model cylinders with diameters of $50 \mathrm{~mm}, 90 \mathrm{~mm}$ and $110 \mathrm{~mm}$ embedded in a silty clay soil. The tests were of short duration and a hyperbolic function was used to obtain the theoretical maximum scour depth.

Rambabu et al. concluded that the equilibrium scour depth decreased with increasing averaged undrained shear strength and increased with increasing Reynolds number. Based on their experimental results they proposed a general relationship for scour in terms of Froude number, $F_{r}=U_{c} /(g h)^{0.5}$, pile Reynolds number, $R_{D}$ (Equation 10), and soil strength:

$S_{e}=D F_{r}^{0.641} R_{D}^{0.640}\left(\frac{S_{u}}{\gamma h}\right)^{-0.976}$

Where $S_{u}$ is the undrained shear strength of the soil; $\gamma$ is the unit weight of the soil; $U_{c}$ is the current velocity; $g$ is the gravitational acceleration, and $h$ is the flow depth.

Debnath and Chaudhuri (2010) undertook experiments using clay and clay-sand sediment mixtures and investigated the effects of clay content, water content, Froude number and applied shear stress on the equilibrium scour depth and associated scour hole geometry as well as the scour development through time. They concluded that for the soils tested with a water content less than $24 \%$ the equilibrium scour depth decreased with increasing clay content. For water content greater than $27 \%$ and increasing clay content they found that the equilibrium scour depth decreased up to $50 \%$ to $70 \%$ clay content and then increased with higher clay content beyond these limits (Figure 4). This point of inflexion was a function of the water content of the clay-sand soil mixture. The increase in scour at each vertex with constant clay content is caused by increasing flow velocity. For fixed values of flow velocity, reductions in scour depth with increasing clay content were apparent as also observed in tests by Dey et al. (2011) and Schindler et al. (2016) also plotted on Figure 4. 


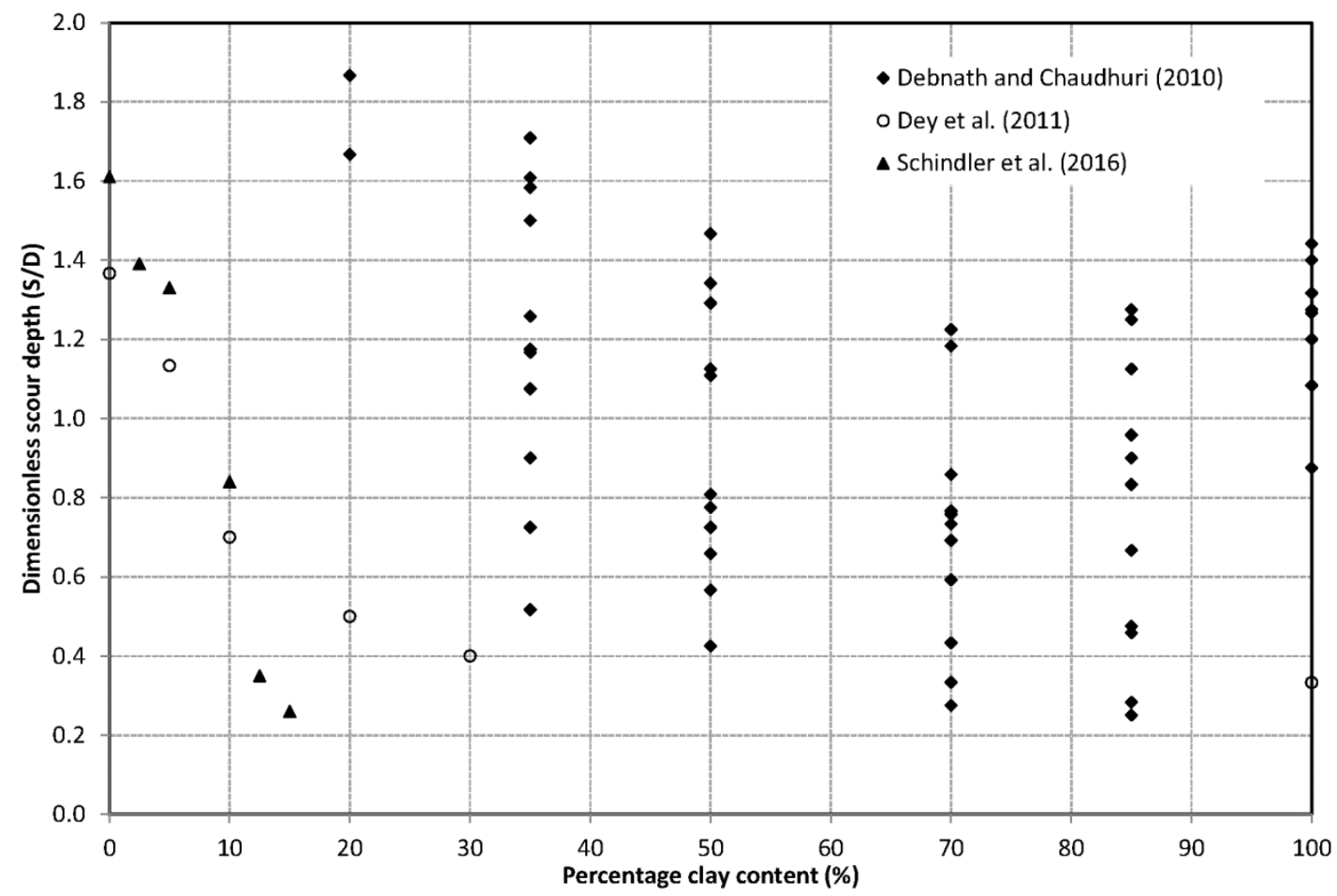

Figure 4. Variation in dimensionless scour depth against percentage clay content in the sample (after Debnath and Chaudhuri, 2010)

Debnath and Chaudhuri (2010) confirmed the shear strength obtained using a shear vane was an important parameter for describing the equilibrium scour depth in the clay-sand mixtures tested. With respect to the formation of the scour, it started at the sides of the cylinder and then propagated downstream in all cases. Under lower shear stress conditions the maximum scour depth was located downstream of the cylinder, whilst at intermediate conditions the scour formed simultaneously at both the upstream and downstream sides of the cylinder. At higher values of shear stress the scour development upstream was greater and faster than that at the downstream side of the cylinder.

Debnath and Chaudhuri (2012) extended their earlier studies investigating local scour around non-cylindrical piers in clay-sand sediment mixtures. Round nosed, square and rectangular piers were chosen, with identical widths to the diameter of the cylinder used in the previous tests $(0.12 \mathrm{~m})$. They examined the effect of clay content, water content and shear strength of the clay-sand sediment mixtures on the scouring process as well as the time development and scour hole geometry.

For the round nosed pier the equilibrium scour depths were typically lower than those obtained for the cylindrical pier, whilst being greater for the square and rectangular shaped structures. They noted once again that the vane shear strength is a key parameter in describing the equilibrium scour depth. Debnath and Chaudhuri (2012) noted three different modes of erosion: Particle-by-particle; in flocs, and "chunk-by-chunk". A similar observation was made by Kothyari et al. (2014). For the particular tests conducted the chunks were of the order of 2 to $5 \mathrm{~mm}$ in size.

Kothyari et al. (2014) investigated scour in the wake region of cylindrical piers using two different sediment types: i.e. fine gravel mixed with clay in proportions ranging between $20 \%$ and $60 \%$ by weight; and fine gravel and fine sand in equal proportion by weight mixed with clay in proportions ranging between $20 \%$ and 
$60 \%$ by weight. They used a range of moisture contents, dry densities, clay content, void ratios and unconfined compressive strengths in the soils tested.

Kothyari et al. noted that the scour holes formed in their tests were significantly different than those formed in non-cohesive sediments and, in a similar fashion to earlier studies (e.g. Ting et al., 2001), significant scouring took place on the downstream side of the piers with, in some cases, negligible scouring taking place at the upstream side. The maximum duration of the tests was about 15.5 hours, therefore, in the longer-term (weeks, months, years) it is likely that the scour pattern will continue to evolve, based on experience from field measurements, however, their results support previous studies which showed scour development in cohesive soils to form at the downstream side of the pier with the maximum scour depth often forming behind the pier.

At lower percentages of clay content $(\leq 30 \%)$ the scour took place on a particle by particle basis, whilst at higher percentages of clay content the sediment scoured in the form of thick flakes. It was also noted that with higher values of unconfined compressive strength and higher percentages of clay content $(>40 \%)$ the sediment scoured in the form of "chunks". This "peeling away" of sediment has been observed by other researchers (Whitehouse et al., 2000; Link et al., 2013). Kothyari et al. also concluded that the clay content and unconfined compressive strength of the soil were significant factors in affecting the scour depth in the wake region of the pier. They do not comment on the effect of the granular material within the soil and as to whether its release in the scouring process led to any abrasion of the surface.

Dey et al. (2011) investigated scour at vertical piles in sand-clay mixtures under waves and their results define scour depth based on clay content. Further, for comparison purposes additional tests were conducted under steady currents in these mixtures. The experiments used a commercial blue clay with an undrained shear strength of $1.75 \mathrm{kPa}$. Different proportions (by weight) of dry clay were mixed with uniform sand $\left(d_{50}=0.18 \mathrm{~mm} ; \sigma_{g}=1.2\right.$, where $\left.\sigma_{g}=\sqrt{d_{84} / d_{16}}\right)$. Unfortunately, no values for the undrained shear strength of these sand-clay mixtures are given within the paper which limits wider comparison based on shear strength.

Dey et al. noted that, for the sediment mixtures tested, when the clay proportion in the sand-clay mixture reached $30 \%$ or above the scour depths achieved can be considered the same as those obtained for the clay alone case albeit that the equilibrium scour depth reduces with increasing proportion of clay content. It is noted that in Figure 4 of Dey et al. for the current only conditions the scour depth for $100 \%$ clay content $(n=1)$ is incorrectly plotted with a S/D value of 1 rather than the correct value of 0.33 as presented in Table 1 of their paper.

The variation of the equilibrium scour depth versus the Keulegan-Carpenter number, $K C$, was found to follow an exponential form as given by Sumer et al. (1992) having different coefficients and exponents. Values for these coefficients and exponents for the range of tests conducted are given within the paper.

Dey et al. (2011) also discussed the time development of scour for the clay-sand mixtures tested. In general the results indicate that the time-scale to scour increases with increasing $\mathrm{KC}$ number and clay content. It is noted that in their tests the equilibrium scour depth was achieved after 50-60 hours, although the experiments were run for a period of 120 hours. The paper describes the time-scale in a non-dimensional form, $T^{*}$, which utilises a median grain size as part of the expression. However, when describing the $100 \%$ clay test this results in a discontinuity in this approach.

Referring back to the earlier part of this review, we have plotted the data of Debnath and Chaudhuri (2010; 2012), Dey et al. (2011), Kothyari et al. (2014) and Schindler et al. on Figure 3. The Dey et al. and Schindler et al. data are comparable and the Debnath and Chaudhuri datasets occupy separate but overlapping 
clusters as do the different soils tested by Kothyari et al. For laboratory conditions Equation 9 (Briaud et al., 1999) provides a conservative prediction.

Straub and Over (2010) SRICOS-EFA method for estimating scour depth of cohesive soils at selected bridges used the in Illinois. EFA tests were run on soil samples from 15 bridge sites. In addition, the soil properties were determined for the soil at each site to enable the relationship between the soil properties and erosion potential, as determined by the EFA, to be studied. Straub and Over found a linear relationship between the threshold critical shear stress and the logarithm of the unconfined compressive strength in undisturbed cohesive soils in Illinois. It should be noted that it has previously been argued (for example, Partheniades, 1965; Arulanandan, 1980) that the use of bulk engineering properties, such as vane shear strength, unconfined compressive strength, and dry unit weight, as erosion predictors is not useful as the erosion of cohesive soils is essentially a surface phenomenon.

Shan et al. (2015) proposed a method for estimating the critical shear stress and erosion rates for a limited range of cohesive soils based around the HEC18 scour framework (Richardson and Davis, 1995). The method uses a number of standard soil parameters in an attempt to limit the requirement for direct erosion testing. Shan et al. present general relationships for both best-fit and design applications, with estimates of critical shear stress determined from the water content, fraction of fines, plasticity index (PI), and unconfined compressive strength. They also present an equation for estimating erosion rates when the bed shear stress exceeds the critical shear stress.

\section{Erosion testing of marine soils}

Lefebvre et al. (1986) tested three eastern Canadian marine clays, investigating soil specimens with an intact structure, specimens remolded and reconsolidated and specimens destructured by consolidation. They found that the high resistance to erosion of the natural intact marine clay is primarily in response to the relatively strong links between clay particles. Whilst the clay structure remains intact the pore water - soil structure does not have a significant effect since the erodibility of the soil at the particle level is controlled by the natural structure of the soil. However, remoulding and reconsolidation of the samples led to high erodibility of some samples, whilst other samples remained resistant to erosion. One of the controlling factors was the salinity of the pore water - soil structure.

Consolidation of intact specimens beyond the pre-consolidation pressure was found, in some instances, to lead to a significant increase in the erodibility of the soil. This mechanical load effect is also found at coastal structures built in chalk where heavy plant was used for installation work and contributed to the initial loosening and detaching of chalk (Dornbusch et al., 2007).

Kamphuis et al. (1990) undertook erosion tests on four natural intact cohesive soils obtained from Ontario, Canada, using a laboratory flume. The soils were extracted from the field using a rectangular cutting frame ( $0.6 \mathrm{~m}$ long by $0.15 \mathrm{~m}$ wide and $0.1 \mathrm{~m}$ deep). The sample and cutting frame were removed together and waxed. Prior to testing the sample was trimmed flush with the cutting frame and both the frame and sample were placed in the flume.

In their tests Kamphuis et al. found that erosion of the samples was controlled by the discontinuities present in the sample rather than the geotechnical properties, with the inception of erosion beginning between a shear stress of 0 and $6 \mathrm{~Pa}$. Erosion of the sample by sand suspension appeared to start once the sand particles became mobile at around a shear stress of 0 to $2 \mathrm{~Pa}$. Erosion at $0 \mathrm{~Pa}$ suggests turbulent fluctuations play a role at very low time-averaged stresses. 
The sand suspension could increase erosion of the sample by up to five times beyond that for the clearwater case and it was concluded that erosion of cohesive soils may be controlled by the size of the particles rather than the properties of the cohesive soils in environments where the flows contain solid particles.

In fact, erosion testing of marine soils in the laboratory is generally considered to be the most reliable approach to assessing field performance. There are a number of suitable in situ erosion equipment that can be used to determine the erosion threshold and erosion rate of the soil. These devices can be applied to barrel core or box core samples obtained from site. A review of erosion devices has been made by Black and Paterson (1997) and Annandale (2006). Devices of this kind include ISIS (HR Wallingford, Wallingford, UK) and SedErode (HR Wallingford) (Williamson and Ockenden, 1996; Mitchener et al., 1996; Black and Paterson, 1997), the Erosion Function Apparatus (EFA) (Briaud et al., 2001) and the Simulator of Erosion Rate Function (SERF) device (Univ. of Florida, Gainesville) (Jiang et al., 2004). Such devices can take a section of core or alternatively use a remoulded sample. By way of example, Chen et al. (2011) used EFA measurements of erosion of marine clay samples from site to demonstrate the erosion potential at the skirt of a large Gravity Base Structure and hence provide justification for scour protection. The different approaches to erodibility testing and their application to offshore projects has been analysed by Whitehouse and Harris (2014). Remoulding effects that take place during foundation installation may be significant in determining the soil strength, and, therefore, the resistance to erosion. More recently Shan et al. (2015) proposed a new ex-situ erosion testing device that mimics the near-bed flow of open channels and can erode cohesive soils within a specified range of shear stresses.

Measurements with the above devices can be carried out on sediment samples from different levels in the seabed to determine the difference in erodibility with depth. This forms a direct input to scour assessment in cohesive soils and comparisons would be possible with the estimates derived from the equations in the Erodibility section.

\section{Abrasion of cohesive soils}

The impact of a seabed surface layer (veneer) of lag gravels from the historical erosion of e.g. a glacial till in providing bed armouring or abrasive properties to the clay soil requires assessment on a case by case basis, as the erodibility of that layer is more tractable to conventional analysis using a Shields approach (Soulsby, 1997). The role of granular material in erosion of a consolidated cohesive bed has been studied by Kamphuis (1983). Two modes of erosion were identified, "sand blasting" caused by impact of individual sand particles moving by saltation and "milling" as a result of sand particles moving as a bed layer. The impact induced erosion resulted in more severe erosion. The study used a site specific soil and only a limited number of tests (six) were conducted, but a number of general conclusions can still be drawn from the results. A fluid containing sand particles will cause erosion of a consolidated cohesive bed at much lower fluid velocities (or shear stresses) than if the fluid was clear. A maximum (local) erosion rate of $2.3 \mathrm{~mm} / \mathrm{hour}$ was obtained in one of the tests, but more typically the erosion rate was of the order of $1 \mathrm{~mm} /$ hour. Longerterm rates of bed degradation of $0.2 \mathrm{~mm} /$ hour for consolidated clay (consolidated to $345 \mathrm{kPa}$ ) were obtained for velocities in the range 0.6 to $2.2 \mathrm{~m} / \mathrm{s}$ at $3 \mathrm{~mm}$ above the bed. Amos et al. (2000) investigated the abrasion of a standard cohesive bed due to saltating gastropod shells in a laboratory mini flume. They noted that the presence of mobile shell material can decrease the erosion thresholds and increase the erosion rates of cohesive sediment by a factor of 20 .

Heuristically, the makeup of the veneer (particle size) and its thickness become important. Based on sediment transport theory (Soulsby, 1997) granular material moves in a carpet of one to two grain diameters 
in thickness. Therefore, veneer thickness (much) larger than this may have a protective effect rather than an eroding profile.

\section{Cyclic loading effects}

Up to this point the processes that have been considered relate directly to the fluid-soil interaction. However, in addition to these processes, scouring may also be influenced by the movement of the monopile in response to an applied load, which offshore could be in response to wind, wave and current action. Further, with respect to offshore wind, the operation of the turbine will induce further dynamic loading within the pile. The corresponding soil response will be different in non-cohesive and cohesive soils, with the movement of the pile in response to loading being dependent on the resultant soil reaction. Therefore, if the pile deflections lead to non-elastic soil deformation a gap will form at the seabed-pile interface which will be filled by water from the surrounding water column (and granular particles). Cyclic loading of the pile will then result in this water being pumped out on each cycle leading to high fluid velocities and pressures at this instance. In cohesive soils the progressive formation of a gap has been observed at the pile-soil interface both in front and behind the pile shaft under cyclic lateral loading of the pile (for example, Pender and Pranjoto, 1996; Tuladhar et al., 2008; and Basack and Bhattacharya, 2009). In addition, cyclic loading of soils also leads to cyclic degradation-hardening mechanisms. This can impact significantly on the soil behaviour. Thiers and Seed (1968) and Gerolymos and Gazetas (2005) note the reduction in soil modulus and undrained shear strength as the two main effects of cyclic loading in cohesive soils. Therefore, the combined soil-waterstructure response becomes important with respect to scouring in cohesive soils.

There have been few studies published into the effect of scour development due to cyclic loading. Reese et al. (1989) reported on experiments carried out to assess the impact on soil loss due to cyclic deflection of a pile under wave forces.

The tests were specific in that they were conducted in still water, with an electric motor used to apply the cyclic load. From their results, Reese et al. reported there was a significant loss of soil resistance under cyclic loading due to the mechanical gapping and ejection of water from the gap as it opens and closes. They noted that grain size was an important factor in scour resistance, with non-cohesive granular soils (coarse to fine sand) less susceptible to soil loss under cyclic loading, whilst cohesive soils appeared to be more susceptible to loss. This is similar to the findings of Basack and Bhattacharya (2009) for example.

Reese et al. used several different soils in their tests including a North Sea clay (with a $28 \%$ sand content). They concluded that clay appears to be more erodible at higher frequencies of loading and that scouring reaches an equilibrium if the cyclic deflection is kept constant.

Extending this to the geotechnical aspects of cyclical lateral loading on offshore piles, the results indicate that there is the potential for an enhanced scouring mechanism under operational loads due to a pumping action of the water in the gap between the pile and the soil, leading to erosion of the soil and a widening of the gap between the pile and the seabed. This effect is not currently considered in empirical scour predictor formulae and may be an important mechanism in the scour development at offshore foundations founded in stiff cohesive soils. 


\section{Evidence from field data}

The evidence database on scour, created primarily from monitoring data collected at UK Offshore Wind Farms (OWF), relates to monopile foundations in different sediment and hydrodynamic environments. Despite the large number of wind farm developments the evidence base related to cohesive soils in the marine environment is still limited.

Some of the early analysis and reviews of the monitoring data from Round 1 and Round 2 offshore wind farm sites in the UK are presented in DECC (2008), COWRIE (2010), Whitehouse et al. (2010), Harris et al.

(2011) and Harris and Whitehouse (2015). Three of the wind farm sites where monitoring data was available for seabed sediments influenced or underlain by clay are Barrow, Kentish Flats and North Hoyle. In all three cases the foundation consists of a circular monopile with no placed scour protection measures around the foundation structures.

The characteristics of the three sites are presented in Table 1 and the scour is described below. 
Table 1: Site characteristics

\begin{tabular}{|c|c|c|c|c|c|c|c|c|c|}
\hline \multirow[t]{2}{*}{ Site } & \multirow[t]{2}{*}{ Description } & \multirow[t]{2}{*}{ Seabed sediment } & $D$ & \multirow[t]{2}{*}{ SP } & \multirow{2}{*}{$\begin{array}{c}h(\mathrm{LAT}) \\
(\mathrm{m})\end{array}$} & \multirow{2}{*}{$\begin{array}{l}\text { MTL } \\
\text { above } \\
\text { LAT } \\
(\mathrm{m})\end{array}$} & \multirow{2}{*}{$\begin{array}{l}\text { Tidal } \\
\text { range } \\
(\mathrm{m})\end{array}$} & \multirow{2}{*}{$\begin{array}{c}U_{p} \\
(\mathrm{~m} / \mathrm{s})\end{array}$} & \multirow{2}{*}{$\begin{array}{l}\text { Annual } \\
\qquad H_{s} \\
(\mathrm{~m})\end{array}$} \\
\hline & & & $(m)$ & & & & & & \\
\hline Barrow OWF & $\begin{array}{l}\text { Open seabed, northwest coast } \\
\text { of England: exposed to waves, } \\
\text { moderate currents, sand and } \\
\text { clay, stable seabed } \\
\text { environment, moderate water } \\
\text { depth. }\end{array}$ & $\begin{array}{l}\text { Fine SAND to muddy } \\
\text { SAND, some } \\
\text { GRAVELS overlying } \\
\text { CLAY; exposed } \\
\text { CLAY }\end{array}$ & 4.75 & No & 12 to 18 & 5.1 & $\begin{array}{l}4.1(n) \\
8.2(s)\end{array}$ & 0.8 & 4.9 \\
\hline Kentish Flats OWF & $\begin{array}{l}\text { Open seabed Thames } \\
\text { Estuary, England: exposed to } \\
\text { waves, moderate currents, } \\
\text { sand and clay, stable seabed } \\
\text { environment, very shallow } \\
\text { water. }\end{array}$ & $\begin{array}{l}\text { Fine SAND; infilled } \\
\text { paleo-channel with } \\
\text { CLAYS and SANDS; } \\
\text { CLAY near surface } \\
\text { or exposed }\end{array}$ & 5 & No & 3 to 5 & 2.74 & $\begin{array}{l}2.9(n) \\
4.7(s)\end{array}$ & 0.9 & $3.3^{*}$ \\
\hline North Hoyle OWF & $\begin{array}{l}\text { Open seabed, North Wales: } \\
\text { ex-posed to waves, moderate } \\
\text { cur-rents, gravel/sandy gravel, } \\
\text { stable seabed environment, } \\
\text { moderate water depth. }\end{array}$ & $\begin{array}{l}\text { Gravelly medium } \\
\text { SAND or sandy } \\
\text { GRAVEL overlying } \\
\text { CLAY }\end{array}$ & 4 & No & 6 to 12 & 5.15 & $\begin{array}{l}4.1(n) \\
6.1(s)\end{array}$ & 1.17 & 4.9 \\
\hline
\end{tabular}

Where: $D$ is the monopile diameter; $h$ is water depth; $H_{s}$ is significant wave height; LAT = lowest astronomical tide; MTL is Mean Tide Level; $\mathrm{n}=$ neap tide; $\mathrm{s}=$ spring tide; $\mathrm{SP}$ is scour protection; $U_{p}$ is peak current speed.

* Depth limited at low water levels. 


\subsection{Barrow OWF}

Barrow OWF is a Round 1 wind farm consisting of $30,4.75 \mathrm{~m}$ diameter monopile foundations, situated about $8 \mathrm{~km}$ southwest of Walney Island in the Irish Sea. Scour was measured at thirteen of the foundations over a number of years. The first scour survey was undertaken in 2005 and showed that in the glacial till to the eastern part of the site, low scour depths (up to $S / D=0.04$ ) were measured. There was some indication that scour depths in the glacial till increased slowly with time following installation (DECC, 2008). Depressions from the spudcan footings of the jack-up barge used for installation were also visible in the seabed.

All thirty foundations were re-surveyed in September 2006. In those areas covered with a thin veneer of sand the scour depths were limited by the thickness of that layer to scour depths of up to and around $0.5 \mathrm{~m}$ or $0.1 D$ in clay sites. Figure 5 shows one of the clay sites with a shallow scour hole of up to $1.2 \mathrm{~m}$ in depth.

The key parameters which determine the amount of scour are the composition and thickness of the surficial and sub-surface sediment layers as well as the prevailing hydrodynamic conditions. The monitoring data from Barrow OWF demonstrated that for the clay dominated sites scour had been restricted by the thickness of the surficial layer and the resistant properties of the underlying soils (Whitehouse et al., 2010). The depth limited cases generally lay to the east of the site where the seabed consisted of glacial till.

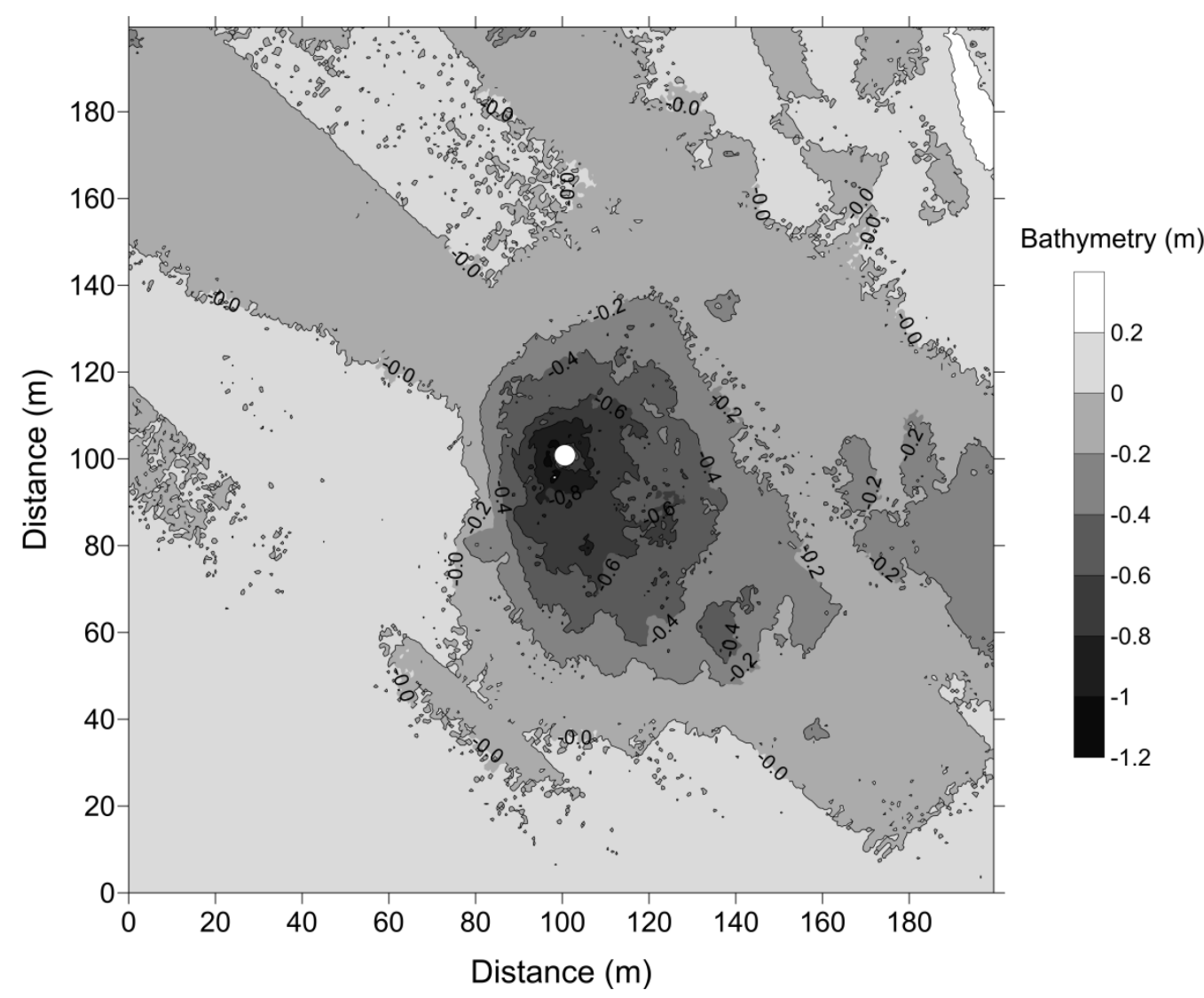

Figure 5. Example of measured scour hole in sand veneer overlying clay seabed at Barrow - scour contours at $0.25 \mathrm{~m}$ intervals below ambient bed level specified as $0 \mathrm{~m}$ 


\subsection{Kentish Flats OWF}

Kentish Flats OWF is located in the outer Thames Estuary, approximately $9 \mathrm{~km}$ off the north Kent coast. The seabed is generally flat and subtly varied, comprising mainly coarse sand, but with varying amounts of shell gravel and small exposures of the underlying clay. Geotechnical surveys also showed the seabed to consist of variable thickness of sand underlain by soft to firm clays overlying London Clay formation. From the last available monitoring data at the wind farm site $S / D$ values of up to 0.4 were obtained. In the initial monitoring surveys, depressions were measured at four of the thirty $5 \mathrm{~m}$ diameter turbine foundations in January 2005 , some three months after completion. It is uncertain whether the initial "scour" depression around the turbines is due to hydraulic scour processes, or whether it was caused by "drawdown" of the soil during foundation installation or a combination of the two processes. The monitoring data also revealed depressions in the seabed in response to where the jack-up barge legs had been present during installation, most probably mainly due to penetration of the legs into the soil rather than through scour processes (see Figure 6).

Assuming the scouring is the principal cause of the depressions at the foundations, the maximum measured depth was less than $0.28 D$ in January 2005, increasing to $0.46 D$ in November 2005 and decreasing again to $0.34 D$ in April 2006. The picture of change was complex as the scour at one location increased with time during the three surveys whereas the scour at the other three locations increased in the first two surveys and then decreased in the last survey. Assuming consistency of the surveys, and the time variations were not an artefact arising from survey error, this suggested that seabed sediment transport processes were able to produce fluctuations in the depth of the scour around the foundations at this site. Figure 6 shows the scour development at Turbines F2 - F4 as measured in January 2005. The scour depths are around $0.9-1.3 \mathrm{~m}$ with $S / D$ ratios of $0.18-0.26$. The authors note that the spudcan depressions to the southwest of the monopile locations have a maximum depth of about $2.0 \mathrm{~m}$.

Whilst the spudcan depressions show no sign of coalescence with the scour holes at the time of the surveys, the features are persistent and may influence scour development in the longer term if the scour hole extents begin to encroach on the depressions.

\subsection{North Hoyle OWF}

North Hoyle OWF is located about $7.5 \mathrm{~km}$ from the north Wales coast offshore of Rhyl. Within the wind farm site the seabed sediments generally consist of sandy gravel or gravelly sand with larger patches of gravel found further offshore. Within these areas the gravels tend to exist as thin veneer overlying sand or boulder clay. Results from various surveys shows the site as being strongly heterogeneous, having variability over very short distances and composed of very poorly sorted sediments. The thirty turbine foundations were installed over the period April to July 2003. Monitoring of the seabed post-installation was carried out over the period August to October 2004.

Some limited scour (less than $0.125 D$ ) was recorded in the 2004 survey at ten of the thirty foundations. In a survey conducted in April-May 2005 no scour was recorded at any of the foundations. No scour protection material was placed around the foundations although there was some redistribution of drill cuttings on the seabed which had arisen during the drill-drive process used to install the foundations. Burial of the inter-array cables was successful with target burial depths achieved in all but about $3 \%$ of the total cable runs. Where full burial was not achieved, rock protection was placed during 2004. 


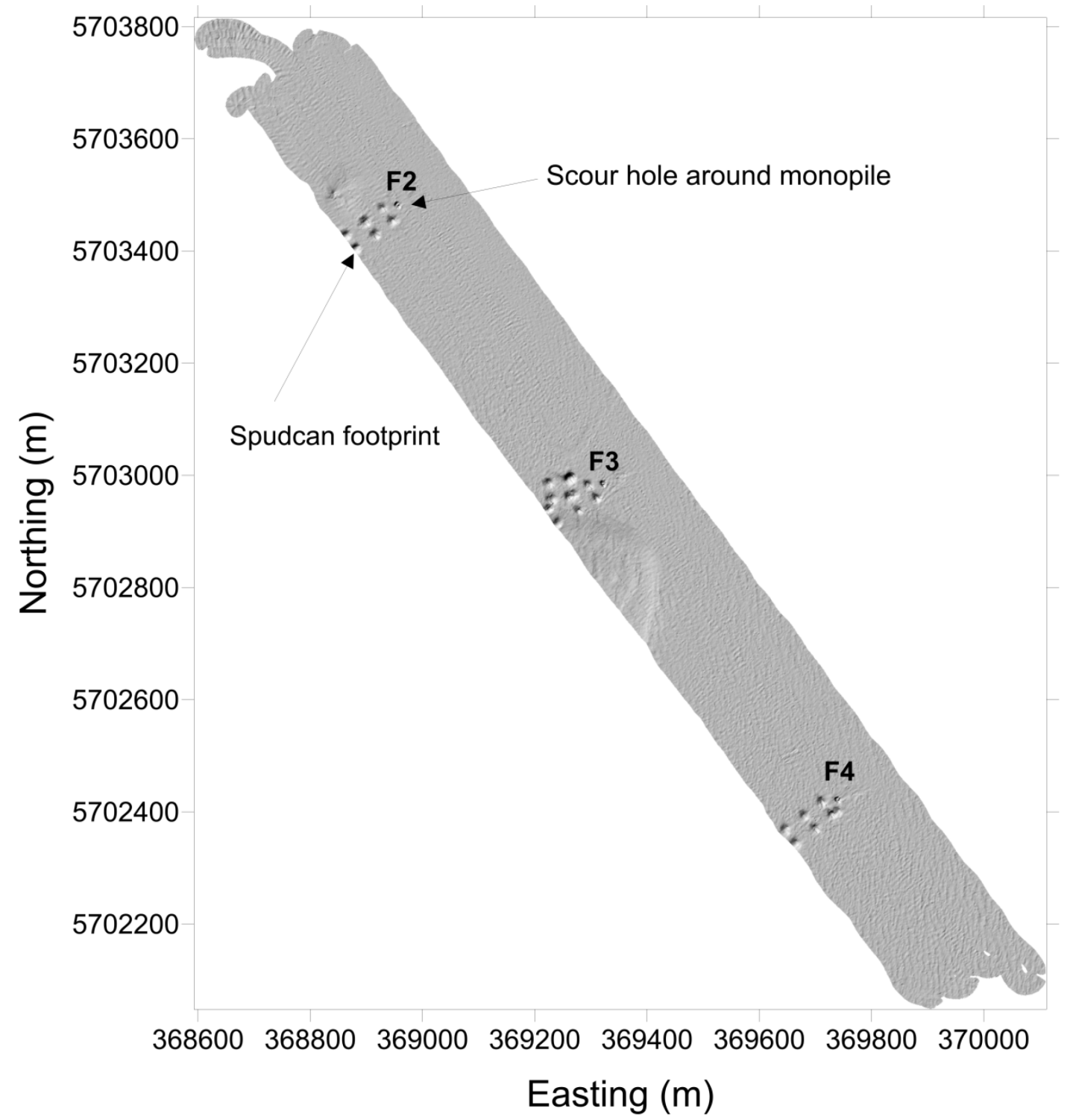

Figure 6. Scour development at turbines F2 - F4, Kentish Flats OWF survey, January 2005. Note jack-up spudcan depressions to southwest of monopiles. (Data collected by EMU Ltd)

\subsection{Scour evolution through time}

Scour development around offshore structures is primarily a function of the hydrodynamics, sedimentology and geotechnical properties at a site. Under tidal flows the current reverses direction with the phase of the tide and, therefore, scour development will take place, typically, in two directions. The time variation in scour depth corresponding to the time of installation of the foundation structure and the monitoring survey(s) is important as there will be a general increase in the scour depth to some equilibrium condition over a timescale that is site specific.

In non-uniform soils it is possible that the equilibrium condition is not achieved over the (design) life of the project and, hence, having a reliable estimate of the time-scale in these type of soils is, arguably, of more importance than that in uniform non-cohesive soils. The time-scale at a site could be estimated by combining 
test results for threshold and rate of erosion with a model for time-series realisations of the wave and current climate.

The evidence from laboratory scale experiments indicate that in clay-sand/clay-gravel/clay-sand-gravel mixtures the time-scale to scour increases with increasing clay content (e.g. Dey et al., 2011; Kothyari et al., 2014). Briaud et al. (1999) state that the low scour rate in clays is most likely related to the large number of shear stress cycles required to overcome the electromagnetic bonds created by the Van der Waals forces between the clay particles, even though these bonds are relatively weak.

The time evolution of scour in offshore sites with non-uniform soils is more difficult to ascertain from available data due to the limited number of surveys available in time and the more gradual scour development. From the monitoring data for Round 1 wind farm sites (Barrow and Kentish Flats) the evidence base, as mentioned earlier, suggests a scour depth that is variable in time and spatially between different locations (Figure 7). The results show a general growth in scour but also reductions in scour depth from one survey to the next. However, inferring a general reduction in scour depth over time from this data should be cautioned against as this may just be a function of the prevailing conditions at the time of the survey rather than some longerterm trend. The data is also limited in time to about 1000 days.

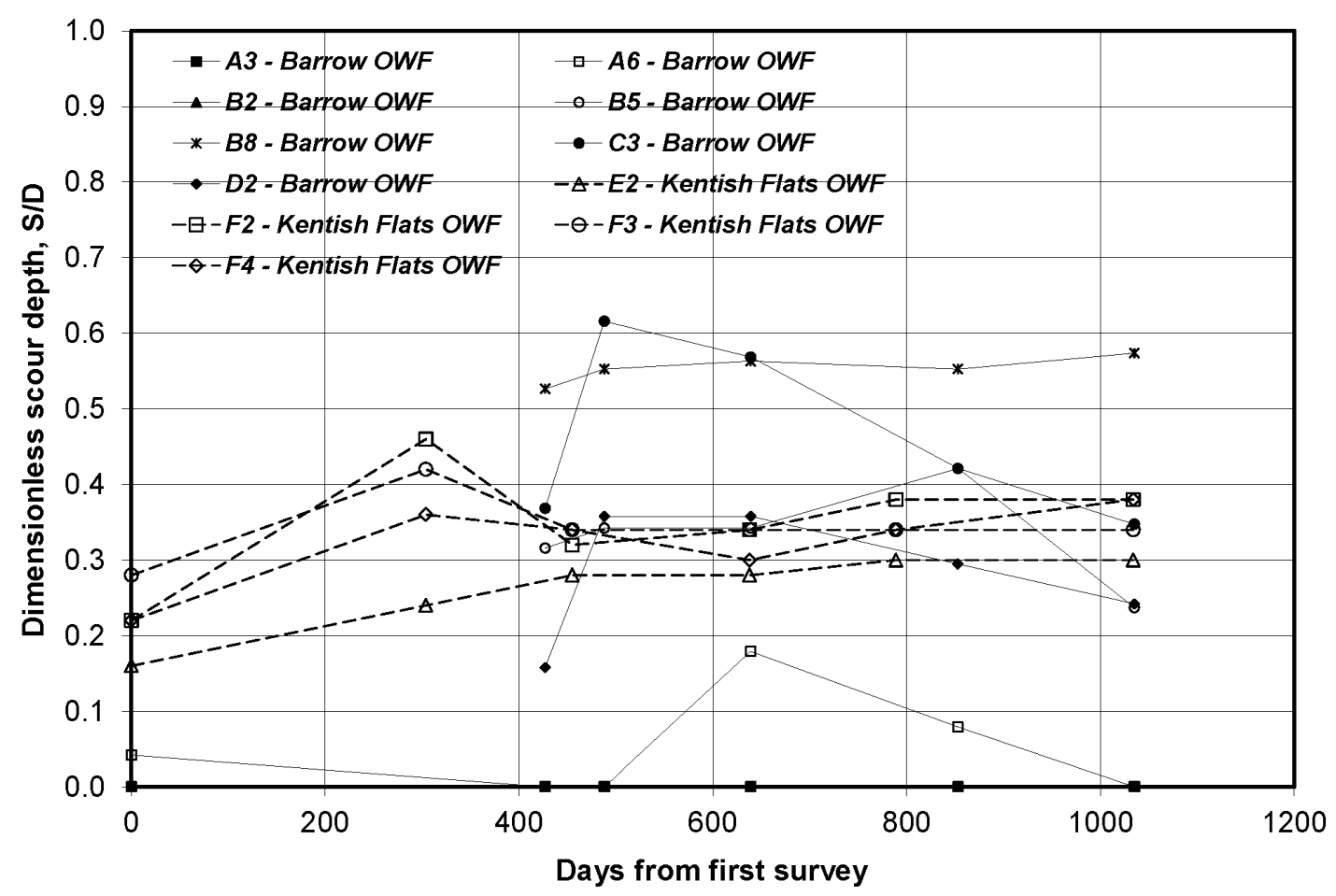

Figure 7. Variation of dimensionless scour depth with time at Barrow and Kentish Flats offshore wind farms 


\section{The challenge}

The requirement to undertake a scour hazard assessment for offshore projects that involve large volume, serial installation of foundations, such as those related to offshore wind farm developments, will inevitably mean that there is a limit to the amount of detailed geotechnical information that can be collected as part of the project beyond the key requirements for foundation design and in cable corridors. Therefore, there is a need to have a reliable scour predictor for a range of ground conditions. Harris et al. (2010) undertook an initial assessment of the Erodibility Index approach for a number of case studies offshore. The approach of Annandale $(1995 ; 2006)$ was used to assess the scour potential at three contrasting offshore locations. The principal attraction of the Erodibility Index method is that it allows for the physical properties of the soil to be considered and although the method does not directly take into account the chemical properties of the material, the mass strength number, $M_{S}$, represents the relative influence of chemical bonding properties of the soil through the unconfined compressive strength and as such represents the bulk strength of the soil. In principal, the method represents an engineering methodology that can be applied using information obtained during geotechnical site investigations. However, to apply the approach to a given location requires a number of key considerations which include:

- The requirement for good information on the soil properties with depth through the seabed, including grain size distributions, density, undrained shear strength, internal angle of friction, etc from the seabed surface to the depth (at least) of $S_{\max }$, the maximum anticipated scour depth.

- Knowledge of the metocean conditions for both typical and extreme events.

Furthermore, the method relies on previously calibrated formulae for the stream power at the seabed and its variation with depth into the scour hole. There is still a requirement to determine the development of scour through time in complex marine soils and this requires further research, especially for soils with multi-modal grading distributions and with distinct layering.

It is also important to determine any adjustment to soil properties that might occur during foundation installation that could affect resistance to scouring and the scour effects of abrasion by the movement of granular sediments is still not well understood (see Section 5).

The key assumption in the Erodibility Index approach is that undrained shear strength can be used as a proxy for the erodibility of soil. What do we know already? Experimental evidence from the laboratory (Sections 2 to 4 ) suggests that in general:

a as water content increases the scour depth increases;

- scour depth decreases with compaction (density) of cohesive soil, although heavy over-consolidation may reduce erosion resistance;

- scour depth increases with increasing Froude No.; and,

- scour depth decreases with increasing clay content.

Therefore, erosion is highly dependent on the degree of consolidation and moisture content and hydrodynamic conditions. The mode of erosion, behind or in front of the pile, appears to be controlled by Reynolds Number and soil properties. Further, whilst the erodibility of cohesive soils can be assessed using approaches such as those proposed by Kamphuis and Hall (1983) or Whitehouse et al. (2000), the formulae are generally only valid for relatively weak soils $\left(S_{u}<100 \mathrm{kPa}\right)$, leaving uncertainty in those marine soils with higher values of $S_{u}$. 
There is also evidence to suggest that erosion of cohesive soils may be controlled by the size of the particles rather than the properties of the cohesive soils in environments were the flows contain mobile non-cohesive granular particles and shelly material.

Using available data from a range of offshore sites and laboratory test data where suitable geotechnical properties are available, it is possible to assess whether the data supports the hypothesis that undrained shear strength can be used as a proxy for the erodibility of soil. Figure 8 presents an initial review of the various data shown as dimensionless scour depth $(S / D)$ against undrained shear strength.

The curve plotted in Figure 8 represents an envelope encompassing the majority of the data only and is not intended to represent a curve fit. There is a significant amount of scatter within the data, particularly at lower values of undrained shear strength. There is an inherent limitation with the laboratory data as these data represent relatively low strength soils compared with those obtained from the majority of the field sites. The exception is the bridge scour data presented by Straub and Over (2010) and some of the offshore data of Melling (2014), which is in a similar range of soil strengths to those of the laboratory tests. A few outliers exist, predominantly from the bridge scour data of Straub and Over. There is no obvious reason for the difference, however, error may be introduced in estimating the soil properties, given the non-uniform makeup of the soil as well as uncertainty in the flow data. The bridge structures are also not directly comparable with the offshore monopiles as in some cases the bridge foundations consist of pile groups or elongated rounded pier structures. There is also an issue with the laboratory data with respect to the equilibrium scour depth, as in many cases the final values have been extrapolated (for example Ting et al., 2001 and Rambabu et al., 2003).

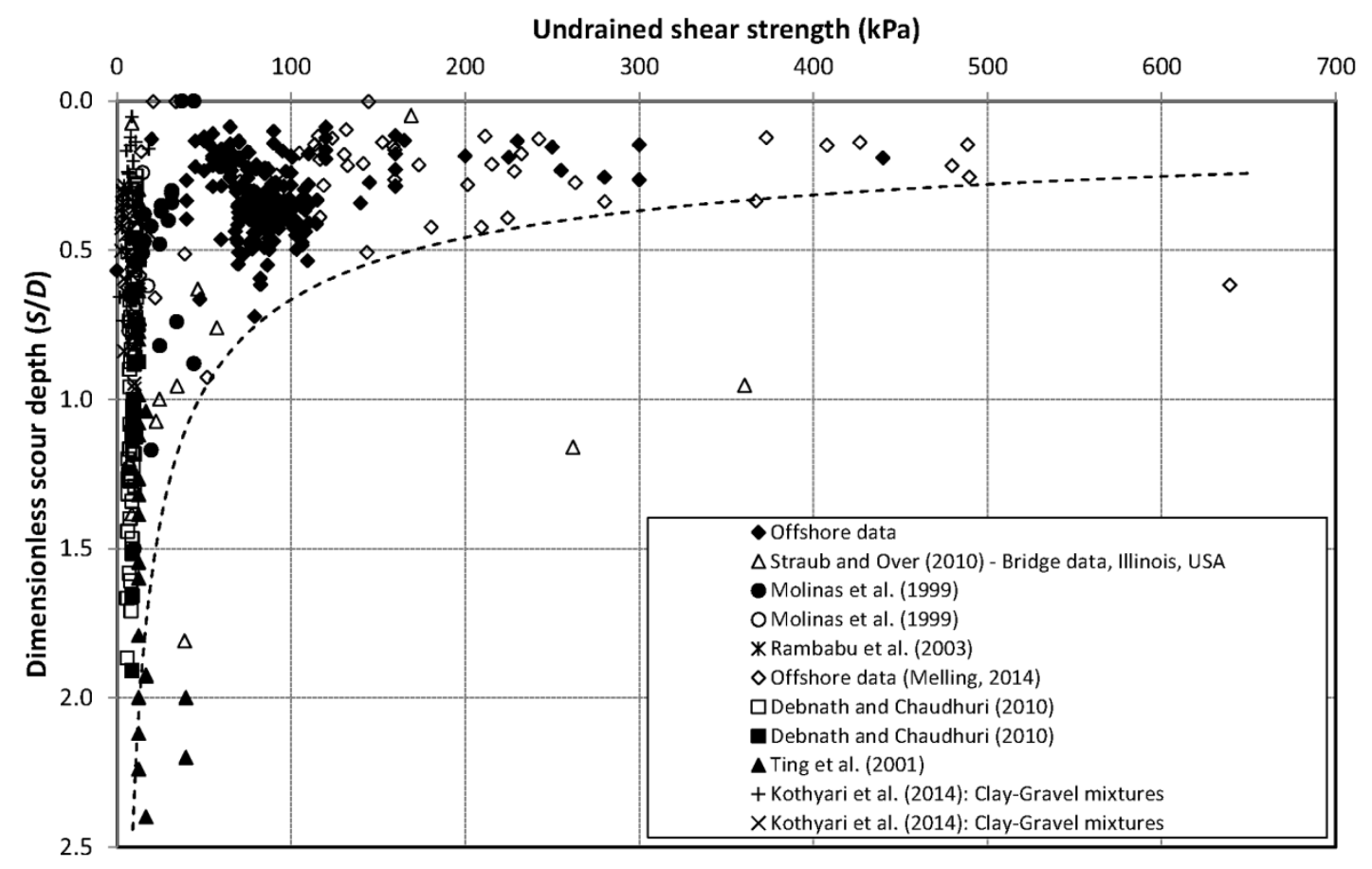

Figure 8. Field and laboratory evidence base of scour depth against undrained shear strength. It should be noted that the data of Ting et al. (2001) is based on generic vane derived undrained strengths rather than test specific vane derived undrained strengths 
The large amount of scatter observed at low values of undrained shear strength may also indicate that in these lower strength soils the scour process is influenced more by the soil properties and the hydrodynamic conditions than in higher strength soils. In the high strength soils it is hypothesised that the scour is controlled more by the soil-structure interaction and the resulting response within the soil matrix than the surface erosion (due to fluid flow), and this would support why, for example Partheniades (1965), considers that bulk engineering properties such as undrained shear strength are not useful for determining the surface erosion of cohesive soils.

There are a number of difficulties with the field data including the representation of the layering effect of the marine soils. By this we mean that in the majority of cases the depth at which the scour has currently developed to has been achieved through eroding through a number of different soil strata with different properties. A decision was made to take the properties of the soil strata to which scouring has currently reached, but this may be somewhat arbitrary given the possible effects that the overlying layer(s) may have on the erodibility of the underlying soil layer. The values of undrained shear strength represent a preconstruction state (i.e. virgin soil properties) and it is unknown what if any change in soil properties may have occurred during and post-installation of the structure, for example due to piling and cyclic loading during operation. In addition, the results do not have any temporal element and, therefore, may only be representative of a transient state, and the equilibrium scour depth has yet to be achieved.

The approach proposed by Rambabu et al. (2003), whilst incorporating parameters to represent soil strength, fails to predict realistic values for the conditions typically encountered for offshore wind, for example, for a pile diameter of $5.2 \mathrm{~m}$; a water depth of $16 \mathrm{~m}$; a current speed of $1.1 \mathrm{~m} / \mathrm{s}$; an undrained shear strength of $95 \mathrm{kPa}$; and an unit weight of soil value of $18.5 \mathrm{kN} / \mathrm{m}^{3}$, the predicted scour depth is unrealistically large (about 59,000 m). Rambabu et al. acknowledge within their paper the potential limitation of their formula and recommend comparison with field data before considering the formula more generally applicable beyond the conditions tested.

The simple relationship for the maximum scour depth proposed by Briaud et al. (1999) may provide a conservative design value for scour depth, with the level of conservatism dependent on parameters such as the pile diameter and the soil strength at the site. For example, using the same values as for the Rambabu et al. case above, the value of $S_{\max }$ is $3 \mathrm{~m}$. Without soil testing the erodibility of the soil cannot be incorporated in further refining this value or its evolution in time.

Taking a random subset of the field data shown in Figure 8 and comparing the results from the field with the Erodibility Index method as proposed by Annandale (2006) suggests that the method is not always conservative (Figure 9). 


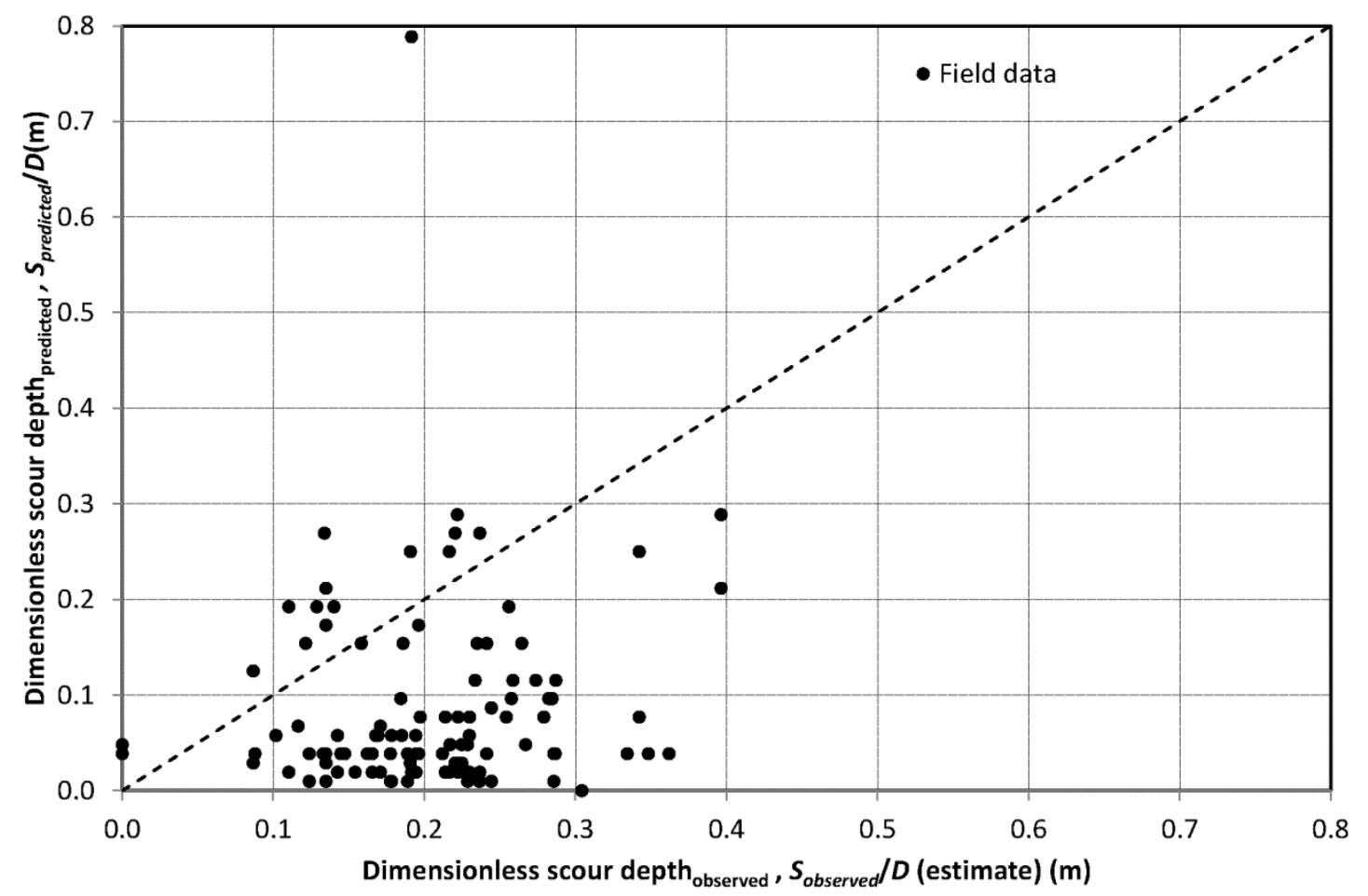

Figure 9. Comparison of predicted scour depth (Erodibility Index method) against measured scour depth

It should also be noted that in previous studies that have made use of the Erodibility Index method they have had access to detailed soil analysis including erodibility testing. This is not a feasible option for large volume installation projects were hundreds of foundations are being installed over an area of tens of kilometres. If it is assumed that the Erodibility Index method is correct for hydraulic processes, then there must be other processes influencing the scour results.

Given that the majority of the offshore data is related to offshore wind then one possible reason for the observed discrepancy with the Erodibility Index approach may lie with cyclic loading effects on the pile. Therefore, following the approach of Randolph (1981) and Randolph and Gourvenec (2011) it is possible to estimate the horizontal deflection of the piles at the seabed subject to cyclic lateral loading using typical wind loading conditions at the various turbine locations.

Applying the elastic continuum approach, Randolph and Gourvenec (2011) propose the following parametric solution for the horizontal deflection, $y_{\text {head }}$ :

$y_{\text {head }}=\frac{\left(E_{p} / G_{c}\right)^{1 / 7}}{\rho_{c} G_{c}}\left[0.27 \frac{H}{L_{\text {crit }} / 2}+0.30 \frac{M}{\left(L_{\text {crit }} / 2\right)^{2}}\right]$

Where: $E_{p}$ is the Young's modulus of a solid pile of equivalent bending rigidity; $G_{c}$ is the characteristic shear modulus; $\rho_{c}$ is a parameter that is introduced to quantify the degree of non-homogeneity of the soil; $L_{c r i t}$ is the critical length of the pile beyond which it behaves as if it is infinitely long; $H$ is the applied load; and, $M$ is the applied moment. Equation (13) was derived from a best fit to parametric finite element studies (Randolph and Gourvenec, 2011). 
If the soil-structure response to cyclic lateral loading influences the observed scour depth then it is expected that the data should reflect this.

Figure 10 shows the results for those offshore sites where a sufficient amount of data exists on the structural characteristics and soil parameters. The data is clustered and this reflects the specific loading and structural characteristics at the various sites (horizontal and moment). However, the results indicate that there appears to be a linear response with respect to cyclic loading of the pile and scour development, albeit with some scatter. It is expected that in stiffer soils the influence of the cyclic loading of the pile will have a greater influence on the scour depth than in weaker soils where the flows are more able to erode the soil. Therefore, it is anticipated that more scatter would exist in the results as the soil strength decreases and the results tend to support this hypothesis.

The results from the analysis suggest that in non-uniform soils where the structure is subject to horizontal deflections at the seabed scour may not be based wholly on the hydraulic erosion of the soil by waves and currents, but also on the mechanical deformation of the seabed at the seabed soil-water-structure interface. This raises a significant question with respect to the prediction of scouring in non-uniform soils, at least in the situation when the soil-structure interaction in response to cyclic loading of the structure can induce deformation of the soil around the base of the foundation. Equations derived for predicting scour in cohesive soils at bridges may not be appropriate for predicting scour at offshore structures. This also explains why such effects have not been observed at bridges as cyclic loading effects are typically small in such structures.

Pile installation effects in modifying the scour response of strong soils could also be important but once the in service cyclic lateral loading has commenced it may mask the initial effects of installation. A conceptual model summarising the relative role of installation and in service loads is offered in Figure 11. The diagram seeks to show that for low strength soils the hydraulic process of scour, as shown to be possible by the experiments reviewed earlier in this paper, is sufficient and may be enhanced by cyclic loads as has been suggested for granular soils by Al-Hammadi and Simons (2016). For high strength soil the additional effects of cyclic loads and installation are expected to be required to contribute to the formation of scour. Controlled large scale testing of the hydraulic and mechanical loads separately and combined in intact soil samples will be required to confirm the relative magnitudes of these effects for a range of soils and pile characteristics. 


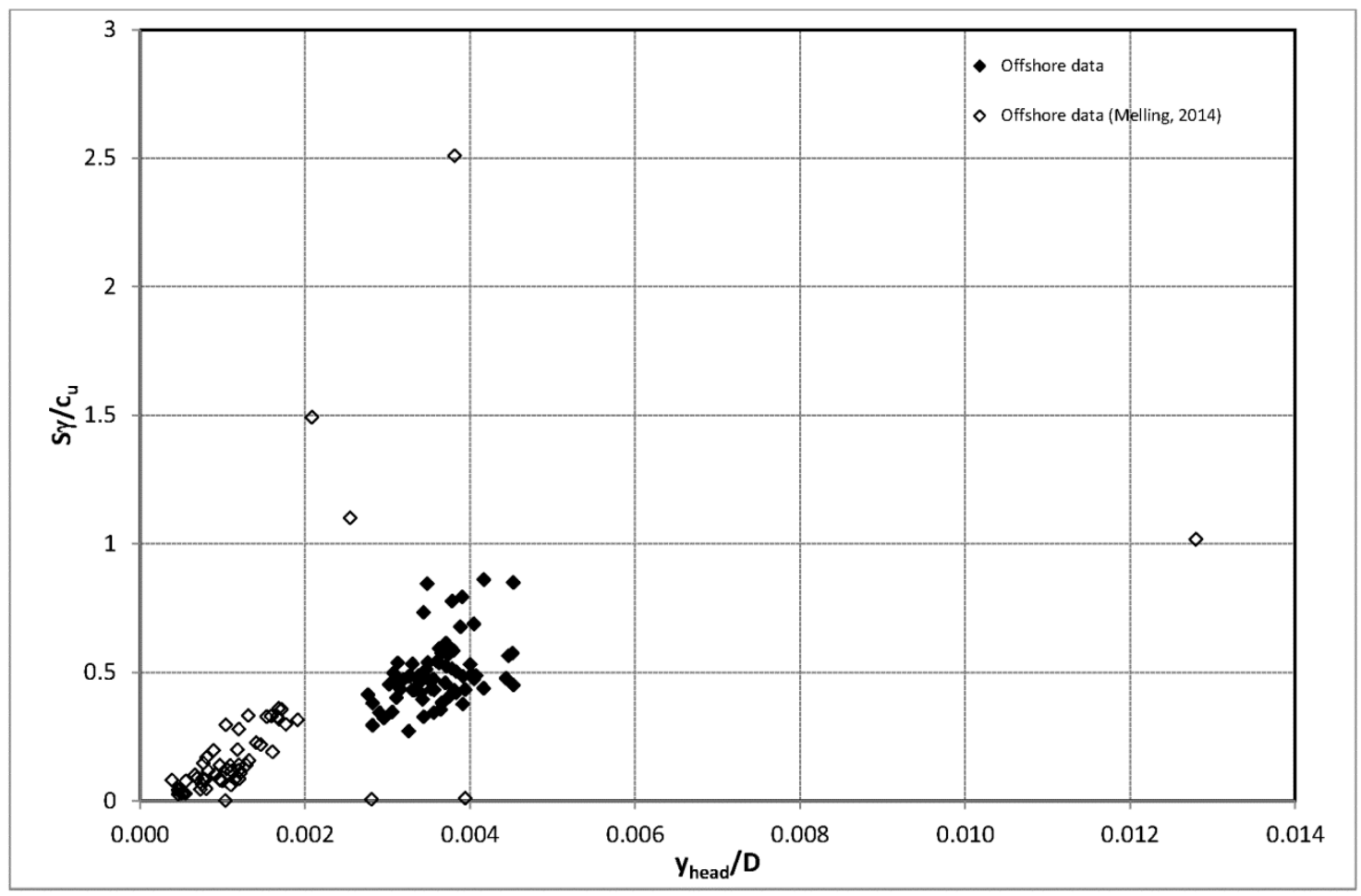

Figure 10. Non-dimensionalised plot of horizontal pile deflection the seabed versus non-dimensionalised scour depth with undrained shear strength.

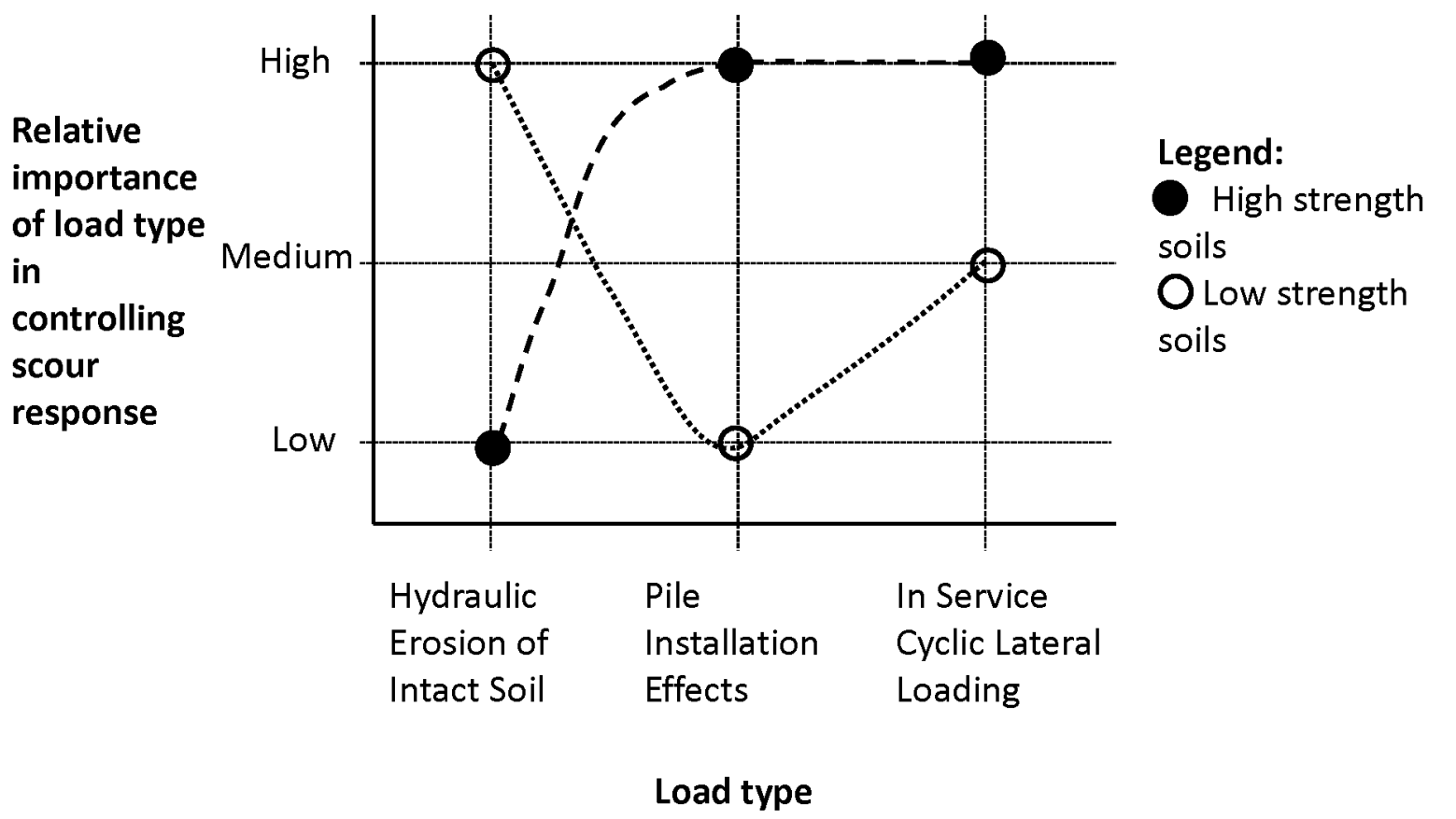

Figure 11. Conceptual model of load effects on scour in cohesive soils. 


\section{Practical application}

Whilst the envelope curve plotted in Figure 8 was not intended as a design curve it does allow for a maximum scour depth to be determined on the basis of an undrained shear strength and a pile diameter. Given that this curve is experiential and derived using data with relatively short time histories (maximum 10 years) the exact position of the curve may not reflect the absolute maximum that can be achieved. However, it does provide a guide with respect to the likely magnitude of scour in these non-uniform cohesive soils found offshore and where the monopile is subject to cyclic loading in the field. For example, assuming a $7 \mathrm{~m}$ diameter $D$ monopile wind turbine foundation located in a soil with the properties as shown in Table 2 derived from site investigation using Cone Penetrometer Tests, it is possible to estimate a maximum scour depth using Figure 8. It is assumed that the sand layer will be eroded, therefore, it is necessary to assess the maximum scour depth in the second soil layer. For an undrained shear strength of $110 \mathrm{kPa}$ the $S / D$ value is about 0.63 , giving a maximum scour depth of about $4.4 \mathrm{~m}$. As this would imply scour development into the third soil layer it is now necessary to assess the maximum scour depth in the third soil layer. For an undrained shear strength of $420 \mathrm{kPa}$ the $S / D$ value is about 0.31 , giving a maximum scour depth of about $2.2 \mathrm{~m}$. Therefore, this implies the third soil layer will resist scour development giving a maximum scour depth below seabed of $2.2 \mathrm{~m}$. In comparison we note that Equation 9 without soil strength represented gives conservative results for $D=7 \mathrm{~m}$ of $2.4 \mathrm{~m}$ and $3.8 \mathrm{~m}$ for representative current velocities of $0.5 \mathrm{~m} / \mathrm{s}$ and $1 \mathrm{~m} / \mathrm{s}$; i.e. the scour depths are $10 \%$ and $70 \%$ larger than the estimate made above.

Table 2. Example soil characteristics

\begin{tabular}{|c|c|c|c|l|}
$\begin{array}{c}\text { Top } \\
(\mathrm{m})\end{array}$ & $\begin{array}{c}\text { Bottom } \\
(\mathrm{m})\end{array}$ & $\begin{array}{c}\text { Undrained } \\
\text { shear strength } \\
(\mathbf{k P a})\end{array}$ & Soil Type & Description \\
\hline 0.0 & 0.4 & - & SAND & Sand, very loose \\
\hline 0.4 & 2.2 & 110 & CLAY & Clay, high strength \\
\hline 2.2 & 6.5 & 420 & CLAYTILL & Clay till, extremely high strength \\
\hline
\end{tabular}

\section{Conclusions}

This paper has reviewed the present evidence from both field and laboratory measurements of scour potential in cohesive soils. In this paper, scour is defined as a local lowering of the ambient bed level at a foundation below the pre-installation or adjacent in service bed levels. Evidence from field data at offshore wind turbine monopile foundations indicates that existing predictive methods for scouring in cohesive material can underpredict the scour depth in these non-uniform soils. Contrary to earlier work (Whitehouse, 2006 ) it is shown that soils with undrained shear strength of $100 \mathrm{kPa}$ are scourable in the open sea marine environment. Further, "scour" has been observed in offshore soils (rock) with undrained shear strengths in excess of $500 \mathrm{kPa}$. On the basis of the offshore field data, two hypotheses have been proposed:

1. that undrained shear strength can be used as a proxy for the erodibility of soil; and,

2. preliminary analysis appears to support a relationship between the soil-structure response to cyclic lateral loading and the observed scour depth. 
From the literature review and the analysis undertaken it has been concluded that:

- The results from laboratory tests of scour in cohesive soils indicate scour forming downstream of the pile in unidirectional flow. Offshore with reversing tidal flow the scour will extend both ways along the tidal axis.

- The empirical equation of Briaud et al. (1999) without the inclusion of soil parameters may give a conservative prediction of scour due to hydraulic forcing. Reductions in scour due to soil strength cannot be made without recourse to erosion testing.

- A range of soil parameters have been used in previous literature as a proxy for resistance to erosion and hence scour potential. The majority of these have been based on laboratory data and are untested with field observations. Evidence from field and laboratory measurements suggests undrained shear strength can be used as a proxy for the erodibility of soil and hence scour (Figure 8).

- The Erodibility Index method (e.g. Annandale, 2006) is still one of very few approaches available to assess scour potential that combines both geotechnical properties and hydrodynamic forcing. However, the relationship may not follow that proposed by Annandale for circular piles.

- Use of the methodology of Annandale (2006) as presented by Harris et al. (2010) may not give conservative answers in the marine environment. However, it should be noted that previous use of the Erodibility Index method elsewhere has used results from detailed soil analysis including erodibility testing.

- From the analysis undertaken, the results suggest that in non-uniform soils where the structure is subject to horizontal deflections at the seabed scour may not be based wholly on the hydraulic erosion of the soil by wave and current action, but also on the mechanical deformation of the seabed at the seabed soilwater-structure interface. This raises a significant question with respect to the prediction of scouring in non-uniform soils, at least in the situation when the soil-structure interaction in response to cyclic loading of the structure can induce deformation of the soil around the base of the foundation. Equations derived for predicting scour in cohesive soils at bridges may not be appropriate for predicting design levels of scour at offshore structures since they do not include this effect.

- Directed process studies on scour due to in service cyclic lateral loading and compilations of field data such as presented in Figure 10 could be used in combination to develop methods further.

- Small scale process studies, such as those reviewed earlier in the paper, are informative, however controlled large scale experiments with intact soil samples of appropriately high strength, a driven pile which is then subjected to structural motion and high Reynolds number flow will help confirm the relative importance of the effects to inform design.

\section{Acknowledgements}

This research was funded by HR Wallingford's scour research programme and was partly undertaken while the lead author was a Visiting Research Fellow in the School of Civil, Environmental and Mining Engineering within the Faculty of Engineering, Computing and Mathematics at the University of Western Australia. The lead author would also like to thank Professor David White for useful discussions whilst at the University of Western Australia. 


\section{References}

Achenbach, E. (1968). "Distribution of local pressure and skin friction around a circular cylinder in cross-flow up to $\operatorname{Re}=5 \times 10^{6}$." Journal of Fluid Mechanics, Vol. 34, No.4, pp. 625-639.

Al-Hammadi, A. and Simons, R.R. (2016). "Effect of vibration on the scour process around cylindrical structures under unidirectional flow in a sandy bed." In: Scour and Erosion, Proc. 8th Int. Conf. on Scour and Erosion, Oxford, 12 - 15 September, (eds.) Harris. J., Whitehouse, R. and Moxon, S., CRC Press, p. $157-161$.

Amos, C.L., Sutherland, T.F., Cloutier, D. and Patterson, S. (2000). "Corrasion of a remoulded cohesive bed by saltating littorinid shells." Cont. Shelf Res., 20, 1291-1315.

Annandale, G.W. (1995). "Erodibility.” Journal of Hydraulic Research, Vol. 33, No.4, pp. 471-494.

Annandale, G.W. (2006). Scour Technology: Mechanics and Engineering Practice. McGraw-Hill, New York, $430 \mathrm{pp}$.

Ansari, S.A., Kothyari, U.C. and Ranga Raju, K.G. (2002). "Influence of cohesion on scour around bridge piers.” Journal of Hydraulic Research, Vol. 40, No. 6, pp. 717 - 729.

Arulanandan, K., Gillogley, E. and Tully, R. (1980). Development of a quantitative method to predict critical shear stress and rate of erosion of natural undisturbed cohesive soils. Tech. Rep. GL-80-5, U.S. Army Engineers, Waterways Experiment Station, Vicksburg, MS.

Basack, S. and Bhattacharya, A.K. (2009). "Influence of lateral cyclic loading on axial response of pile with particular reference to disturbance produced on ground surface." Electronic Journal of Geotechnical Engineering.

Black, K. S. and Paterson, D. M. (1997)."Measurement of the erosion potential of cohesive marine sediments: A review of current in situ technology." J. Marine Environ. Engrg., 4(1), 43-83.

Briaud, J-L., Ting, C.K., Chen, H.C., Gudavalli, R., Perugu, S. and Wei, G. (1999). "SRICOS: Prediction of scour rate in cohesive soils at bridge piers." J. of Geotechnical and Geoenvironmental Engng., Vol. 125, No. 4, April, ASCE, pp. $237-246$.

Briaud, J.-L., Ting, F.C.K., Chen, H.C., Cao, Y., Han, S.W. and Kwak, K.W. (2001). "Erosion function apparatus for scour rate predictions." Journal of Geotechnical and Geoenvironmental Engineering, Vol. 127, p. 105-113.

Chapuis, R.P. (1986). "Quantitative measurement of the scour resistance of natural solid clays." Can. Geotech. 1. 23, p. 132-141.

Chee, R.K.W. (1982). Live-bed scour at bridge piers. Report No.290, School of Engineering, The University of Auckland, Auckland, New Zealand, $79 \mathrm{p}$.

Chen, Z., Hurdle, D., Kram, N., Lomonaco, P. and Cornett, A. 2011. "Design and testing of scour protection for Adriatic LNG GBS." Proceedings of the ASME $201130^{\text {th }}$ International Conference on Ocean, Offshore and Arctic Engineering, OMAE2011, June 19-24,2011, Rotterdam, The Netherlands. Paper OMAE201149385.

Chiew, Y.M. (1984). Local scour at bridge piers. Ph.D. thesis, Department of Civil Engng, Auckland University, New Zealand, 200 p. 
COWRIE (2010). A Further Review of Sediment Monitoring Data. Final Report prepared by ABPmer Ltd, HR Wallingford Ltd and CEFAS for the Research Advisory Group, Project Ref. ScourSed-09, March, 115 p.

Debnath, K. and Chaudhuri, S. (2010). "Laboratory experiments on local scour around cylinder for clay and clay-sand mixed beds." Engineering Geology, 111, Elsevier, pp. 51 -61.

Debnath, K. and Chaudhuri, S. (2012). "Local scour around non-circular piers in clay-sand mixed cohesive sediment beds." Engineering Geology, 151, Technical Note, Elsevier, pp. 1 -14.

DECC (2008). Dynamics of scour pits and scour protection - Synthesis report and recommendations (Milestones 2 and 3). Final Report prepared by HR Wallingford Ltd, ABP Marine Environmental Research Ltd and Centre for Environment, Fisheries and Aquaculture Science for the Research Advisory Group, Department of Energy and Climate Change (DECC) and Department for Environment, Food and Rural Affairs (Defra).

Dey, S., Helkjær, A., Sumer, B.M., and Fredsøe, J. (2011). "Scour at vertical piles in sand-clay mixtures under waves." Journal of Waterway, Port, Coastal, and Ocean Engineering, Vol. 137, No. 6, November, pp. 324-331.

Dornbusch, U., Robinson, D.A., Williams, R.B.G. and Moses, C.A. (2007). "Chalk shore platform erosion in the vicinity of sea defence structures and the impact of construction methods." Coastal Engineering, 54, 801-810.

Ettema, R. (1980). Scour at bridge piers. Ph.D. thesis, Department of Civil Engng, Auckland University, New Zealand.

Ettema, R., Kirkil, G., and Muste, M. (2006). "Similitude of large-scale turbulence in experiments on local scour at cylinders." Journal of Hydraulic Engineering, Vol. 132, No.1, pp. 33 - 40.

Gerolymos, N. and Gazetas, G. (2005). "Constitutive model for 1-D cyclic soil behaviour applied to seismic analysis of layered deposits." Soils and Foundations, 45(3): pp. 147 - 159.

Harris, J.M, Whitehouse, R.J.S. and Sutherland, J. (2010). "Scour Assessment in Complex Marine Soils An Evaluation through Case Examples." In: Proceedings of the Fifth International Conference on Scour and Erosion (ICSE-5), (eds.) Burns, S.E., Bhatia, S.K., Avila, C.M.C., and Hunt, B.E., Holiday Inn Golden Gateway, San Francisco, California, Nov. 7 -10, ASCE, Geotechnical special publication No. 210, pp. $450-459$.

Harris, J.M., Whitehouse, R.J.S. and Sutherland, J. (2011). "Marine scour and offshore wind - lessons learnt and future challenges." Proceedings of the ASME 2011 30th International Conference on Ocean, Offshore and Arctic Engineering, OMAE2011, June 19-24, 2011, Rotterdam, The Netherlands, OMAE2011-50117.

Harris, J.M. and Whitehouse, R.J.S. (2015). "Scour prediction in non-uniform soils: Undrained shear strength and erodibility." In: Scour and Erosion, Proc. 7th Int. Conf. on Scour and Erosion, The University of Western Australia, 2 - 4 December, 2014, (eds.) Cheng. L., Draper, S. and An, H., CRC Press, p. $705-714$.

Hosny, M.M. (1995). Experimental study of local scour around circular bridge piers in cohesive soils. Ph.D. thesis, Civil Engng. Dept., Colorado State University, Fort Collins, Colorado, 177 p.

Ivarson, W.R. (1999). "Scour and erosion in clay soils." In: Stream Stability and Scour at Highway Bridges: compendium of papers ASCE Water Resources Engineering Conferences 1991 to 1998, (eds.) Richardson, E.V. and Lagasse, P.F., ASCE, p. $104-119$. 
Jiang, J., Ganju, N.K and Mehta, A.J. (2004). "Estimation of contraction scour in riverbed using SERF." Journal of Waterway, Port, Coastal, and Ocean Engineering, 130, pp. 215-218.

Kamphuis, J.W. (1983). "On the erosion of consolidated clay material by a fluid containing sand." Can. J. Civ. Eng., 10, pp. $223-231$.

Kamphuis, J.W., Gaskin, P.N. and Hoogendoorn, E. (1990). "Erosion tests on four intact Ontario clays." Can. Geotech. J., 27, pp. $692-696$.

Kamphuis, J.W. and Hall, K.R. (1983). "Cohesive material erosion by unidirectional current." Journal of Hydraulic Engineering, Vol. 109, No. 1, January, ASCE, pp. 49 - 61.

Kamphuis, J.W. (1990). "Influence of sand or gravel on the erosion of cohesive sediment." Journal of Hydraulic Research, Vol. 28, No.1, pp. 43 - 53.

Kothyari, U.C., Kumar, A. and Jain, R.K. (2014). "Influence of cohesion on river bed scour in the wake region of piers." Journal of Hydraulic Engineering, Vol. 140, No. 1, January, ASCE, pp. 1 - 13.

Link, O., Klischies, K., Montalva, G. and Dey, S. (2013). "Effects of bed compaction on scour at piers in sand-clay mixtures." Journal of Hydraulic Engineering., Technical Note, Vol. 139, No. 9, September, p. $1013-1019$.

Lefebvre, G., Rohan, K. and Milette, J-P. (1986). "Erosivity of intact clay: Influence of the natural structure." Can. Geotech. J., 23, pp. $427-434$.

Melling, G.J. (2014). Hydrodynamic and geotechnical controls of scour around offshore monopiles. Ph.D thesis, University of Southampton Faculty of Natural and Environmental Sciences, Ocean and Earth Sciences.

Mirtskhulava, Ts.E.(1966). "Erosional stability of cohesive soils." Journal of Hydraulic Research, Vol. 4, No. 1 , p. $37-50$.

Mirtskhoulava, Ts.E. (1991). "Scouring by flowing water of cohesive and noncohesive beds." Journal of Hydraulic Research, Vol. 29, No. 3, p. 341-354.

Mitchener, H.J., Whitehouse, R.J.S., Soulsby, R.L. and Lawford, V.A. (1996). Development of SedErode Instrument for In-Situ mud erosion measurements. Report TR17, HR Wallingford, 17 pp. (+tables and figures).

Molinas, A., Jones, S. and Hosny, M. (1999). "Effects of Cohesive Material Properties on Local Scour Around Piers." J. of the Transportation Research Board, Transportation Research Record, No. 1690, National Academy Press, pp. 164-175.

Partheniades, E. (1965). "Erosion and Deposition of Cohesive Soils." J. Hydraulics Div., Proc., American Society of Civil Engineers, Vol. 91, No. HY1, Proc. Paper 4204, pp. 105-138.

Pranjoto, S. and Pender, M.J. (2003). "Gapping effects on the lateral stiffness of piles in cohesive soil." In: Proceedings of the Pacific Conference on Earthquake Engineering, Christchurch, New Zealand, 13-15 February 2003. Paper No. 096, New Zealand Society for Earthquake Engineering.

Rambabu, M., Narasimha Rao, S. and Sundar, V. (2003). "Current-induced scour around a vertical pile in cohesive soil." Ocean Engng., 30, Elsevier, pp. 893 - 920.

Randolph, M.F. (1981). "The response of flexible piles to lateral loading." Geotechnique, Vol.32, No. 2, pp. $247-259$. 
Randolph, M., and Gourvenec, S. (2011). Offshore geotechnical engineering. Spon Press, Oxfordshire, UK, $528 \mathrm{pp}$.

Reese, L.C., Wang, S.T. and Long, J.H. (1989). "Scour from cyclic lateral loading of piles." In: Proceedings $21^{\text {st }}$ Offshore Technology Conference, Paper OTC 6005, Houston, Texas, 1 - 4 May, pp. $395-402$.

Richardson, E.V. and Davis, S.R. (1995). Evaluating scour at bridges. Report No. FHWA-IP-90-017, Hydraulic Engineering Circular No. 18 (HEC-18), Third Edition, Office of Technology Applications, HTA-22, Federal Highway Administration, U.S. Department of Transportation, Washington, D.C., U.S.A., November, $204 \mathrm{p}$.

Schindler, R.J., Stripling, S., Whitehouse, R.J.S. and Harris, J.M. (2016). The influence of physical cohesion on scour around a monopile. In: Scour and Erosion, Proc. 8th Int. Conf. on Scour and Erosion, Oxford, 12 - 15 September, (eds.) Harris. J., Whitehouse, R. and Moxon, S., CRC Press, p. $325-334$.

Shan, H., Shen, J., Kilgore, R. and Kerenyi, K. (2015). Scour in Cohesive Soils. Publication No. FHWA HRT 15-033, U.S. Dept. of Transportation, Federal Highway Administration, 96 p.

Shen, H.W., Schneider, V.R. and Karaki, S.S. (1969). "Local scour around bridge piers." J of the Hydraulics Div., Vol. 96, HY6, ASCE, pp. 1919 - 1940.

Smerdon, E.T. and Beasley, R.P. (1959). The tractive force theory applied to stability of open channels in cohesive soils. Research Bulletin 715, College of Agriculture, University of Missouri, Columbia, USA.

Soulsby, R.L. (1997). Dynamics of marine sands: A manual for practical applications. Thomas Telford Publications, London, $249 \mathrm{pp}$.

Sumer, B. M., Fredsøe, J., and Christiansen, N. (1992). Scour around vertical pile in waves. J. Waterway, Port, Coastal, Ocean Eng., Vol. 118, No.1, pp. 15-31.

Straub, T.D. and Over, T.M. (2010). Pier and contraction scour prediction in cohesive soils at selected bridges in Illinois. Research Report ICT-10-074, Illinois Department of Transportation, August, 119 pp.

Terzaghi, K., Peck, R.B. and Mesri, G. (1996). Soil mechanics in engineering practice. 3rd Edition, John Wiley \& Sons Inc., 592 pp.

Thiers, G.R., and Seed, H.B. (1968). "Cyclic stress-strain characteristics of clay." Journal of the Soil Mechanics and Foundation Division, ASCE, 94(SM2): pp. 555 - 569.

Ting, F.C.K., Briaud, J-L., Chen, H.C., Gudavalli, R., Perugu, S. and Wei, G. (2001). "Flume tests for scour in clay at circular piers." J. Hydr. Engng., Vol. 127, No. 11, ASCE, New York, pp. 969 - 978.

Tuladhar, R., Maki, T. and Mutsuyoshi, H. (2008). "Cyclic behavior of laterally loaded concrete piles embedded into cohesive soil." Earthquake Engineering and Structural Dynamics, 37(1): pp. $43-59$.

Van Ledden, M., van Kesteren, W.G.M. and Winterwerp, J.C. (2004). "A conceptual framework for the erosion behaviour of sand-mud mixtures." Continental Shelf Res., 24, pp. $1-11$.

Williamson, H.J. and Ockenden, M.C. (1996). "ISIS - an instrument for measuring erosion stress in-situ." Estuarine, Coastal and Shelf Science, Vol. 42, 1-1.

Whitehouse, R.J.S. (2006). "Scour at coastal structures." In: Proceedings of the Third International Conference on Scour and Erosion, November 1-3, Amsterdam, CURNET, Gouda, pp. 52 -59. 
Whitehouse, R.J.S. and Harris, J.M. (2014). "Scour prediction offshore and soil erosion testing." Proceedings of the ASME 2014 33rd International Conference on Ocean, Offshore and Arctic Engineering, OMAE2014, June 8-13, 2014, San Francisco, California, USA. Paper OMAE2014-24271.

Whitehouse, R.J.S., Harris, J.M., Sutherland, J. and Rees, J. (2010). "The nature of scour development and scour protection at offshore windfarm foundations.” Mar. Pollut. Bull., 62(1), p. 73 - 88.

Whitehouse R., Soulsby R., Roberts W., and Mitchener H. (2000). Dynamics of estuarine muds: A manual for practical applications. Thomas Telford Publishing, London, $210 \mathrm{pp}$.

Winterwerp, J.C. and van Kesteren, W.G.M. (2004). Introduction to the physics of cohesive sediment in the marine environment. Developments in Sedimentology, 56, Series Ed. Van Loon, T., Elsevier, Amsterdam, The Netherlands, 466 pp. (+Appendices). 